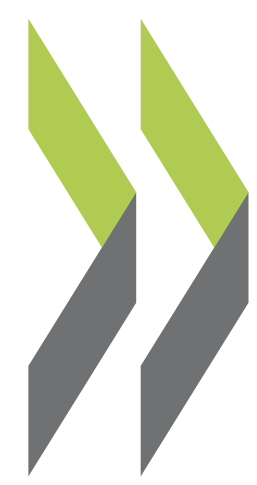

OECD Working Papers on International Investment 2017/03

Addressing the balance of interests in investment treaties: The limitation of fair and equitable treatment David Gaukrodger provisions to the minimum standard of treatment under customary international law 


\section{OECD WORKING PAPERS ON INTERNATIONAL INVESTMENT}

OECD Working Papers should not be reported as representing the official views of the OECD or of its member countries. The opinions expressed and arguments employed are those of the authors.

Working Papers describe preliminary results or research in progress by the author(s) and are published to stimulate discussion on a broad range of issues on which the OECD works. Comments on Working Papers are welcomed, and may be sent to investment@oecd.org or the Investment Division Directorate for Financial and Enterprise Affairs, OECD, 2 rue André-Pascal, 75775 Paris Cedex 16, France.

The international investment working paper series - including policies and trends and the broader implications of multinational enterprise - is designed to make available to a wide readership selected studies undertaken under the aegis of the OECD Investment Committee, by OECD staff, or by outside consultants working on OECD Investment Committee projects.

The papers are generally available only in their original language English or French with a summary in the other if available.

OECD WORKING PAPERS ON INTERNATIONAL INVESTMENT are published on www.oecd.org/investment/working-papers.htm.

This document and any map included herein are without prejudice to the status of or sovereignty over any territory, to the delimitation of international frontiers and boundaries and to the name of any territory, city or area.

You can copy, download or print OECD content for your own use, and you can include excerpts from OECD publications, databases and multimedia products in your own documents, presentations, blogs, websites and teaching materials, provided that suitable acknowledgment of OECD as source and copyright owner is given. All requests for commercial use and translation rights should be submitted to rights@oecd.org. 


\title{
Addressing the Balance of Interests in Investment Treaties
}

\author{
The Limitation of Fair and Equitable Treatment Provisions \\ to the Minimum Standard of Treatment under Customary International Law
}

\author{
By \\ David Gaukrodger
}

\begin{abstract}
The fair and equitable treatment (FET) provision has leapt to prominence in the last 15 years as the principal ground of liability at issue in many if not most investment treaty arbitration claims. In debates about the impact of investment treaties on the right to regulate, FET is second only to investor-state dispute settlement (ISDS) as the most-cited provision.

This paper examines government action to address the balance between investor protection and the right to regulate by limiting FET provisions. It considers in particular limiting the FET provision to the minimum standard of treatment under customary international law. The paper reviews the difference between such clauses (referred to as MST-FET) and autonomous FET clauses that are not linked to the minimum standard of treatment. The paper notes growing use of an express MST-FET approach in many regions.

NAFTA governments' views about the nature of the MST-FET standard, how it is identified, and its content are then examined in detail. An initial focus on NAFTA, while limited, is justified due to many singularities in NAFTA, including numerous government interpretations of MST-FET since 1994, their availability to the public and the comparatively higher success rate of NAFTA governments in defending FET claims. The paper concludes with brief comparisons between the government views and the views of ISDS tribunals and commentators.
\end{abstract}

Authorised for release by Pierre Poret, Director, OECD Directorate for Financial and Enterprise Affairs

JEL Classification: F02, F13, F21, F23, F53, F60, H11, H40, K4, K23, K29, K33

Keywords: investment treaties; bilateral investment treaties; investor protection; fair and equitable treatment; minimum standard of treatment; customary international law; state practice; opinio juris; right to regulate; regulatory autonomy; policy space; investment treaty policy; investor-state dispute settlement; ISDS; NAFTA; investment arbitration; international economic law; balancing of interests; balancing of policy goals; foreign investment; international investment; international investment law; international investment agreements. 


\section{TABLE OF CONTENTS}

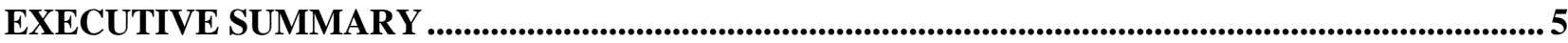

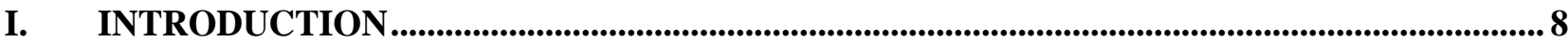

II. FAIR AND EQUITABLE TREATMENT (FET) PROVISIONS IN INVESTMENT

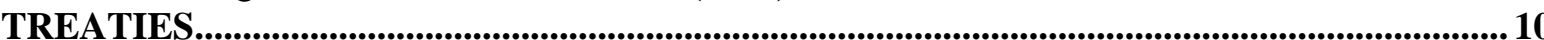

A. "Bare" FET clauses in BITs are frequently seen by arbitral tribunals today as autonomous from customary international law, a marked change from the situation as seen at the OECD in 2004.

B. A determination that a FET clause is autonomous increases the scope for arbitral interpretation of the clause

C. The growth of FET claims and of the list of norms allegedly included in FET

D. A number of ISDS tribunals have found that there is little or no distinction between autonomous FET and FET that is limited to the minimum standard of treatment under customary international law (MST-FET).

E. FET has become an important component of debates about the impact of treaties on regulation .....

III. FET PROVISIONS LIMITED TO THE MINIMUM STANDARD OF TREATMENT UNDER CUSTOMARY INTERNATIONAL LAW ("MST-FET PROVISIONS")

HAVE GROWING RELEVANCE..

A. Governments have included express MST-FET provisions in a growing range of treaties between major economies

B. At least until its content is stabilised, intense investor and tribunal attention to FET likely mean that MST-FET will frequently be subject to interpretation by governments and applied by tribunals

C. Finding MST-FET norms -- the importance of studying government action and government views in identifying customary international law norms

IV. THE VALUE AND LIMITS OF GOVERNMENT VIEWS ABOUT MST-FET IN NAFTA

A. At present, NAFTA has singularities that make it an important initial reference.

1. The outcomes in NAFTA FET cases differ markedly from those under FET provisions in other treaties

2. NAFTA provides unparalleled access to government interpretations of MST-FET.

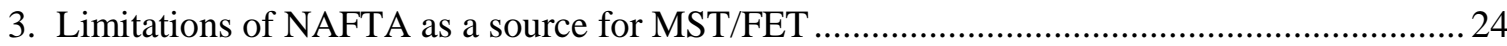

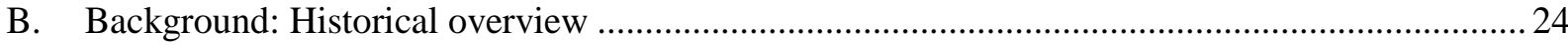

1. Government reaction to early expansive readings of FET in NAFTA in ISDS: the 2001

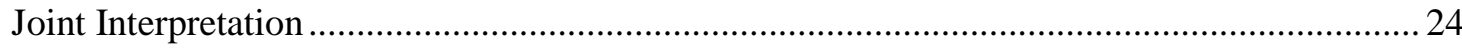

2. MST-FET Claims under NAFTA following the 2001 Joint Interpretation .................................. 25

3. The 2015 Bilcon decision and NAFTA government reactions .................................................. 27 


\section{NAFTA GOVERNMENT VIEWS ABOUT THE NATURE OF THE MST-FET}

A. The nature of the MST-FET inquiry and the limited role of the ISDS tribunal in resolving MST-FET claims.

1. The MST-FET standard under customary international law is determined by reference to a general and consistent practice of States that they follow from a sense of legal obligation

2. The signing of many BITs does not create customary international law

3. Domestic law, domestic court decisions and official declarations by relevant state actors are relevant state practice for determining whether a particular rule exists as part of MST-FET

4. Government submissions in disputes are an important source of state practice ........................ 31

5. Arbitral decisions have limited relevance to interpreting MST-FET ......................................... 32

B. The claimant's burden of proof with regard to the law and the role of the tribunal ........................34

VI. NAFTA GOVERNMENT INTERPRETATIONS OF THE CONTENT OF MST-FET ............35

A. Overall views

1. The MST is an umbrella concept for a set of discrete rules. .35

2. Few norms have been established as part of the MST under customary international law .......36

3. Customary international law can evolve but proof is required .................................................. 37

4. The MST is an absolute and minimum standard that establishes a floor .................................. 37

5. There is a high standard for establishment of a breach of the minimum standard...................... 37

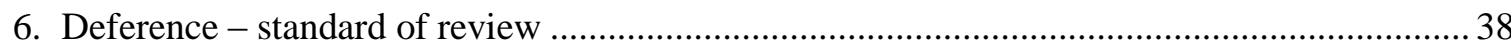

7. Violation of domestic administrative law is insufficient to show breach of MST-FET ............38

8. The US policy of not granting greater substantive protections to treaty-covered foreign investors than to US investors under US law is a relevant consideration

B. NAFTA government views on specific norms proposed by claimants, commentators or ISDS cases as part of Alleged FET Lists

1. Although NAFTA claimants have rarely provided evidence of the two elements of customary international law in their submissions, NAFTA governments have generally decided not to rest their defence in ISDS cases solely on that basis

2. NAFTA governments have recognised the obligation not to deny justice in adjudicatory proceedings as a rule established under MST-FET.

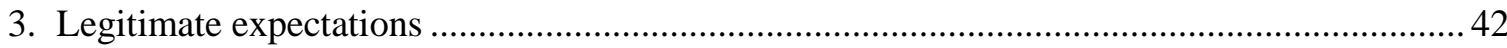

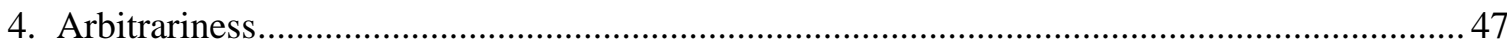

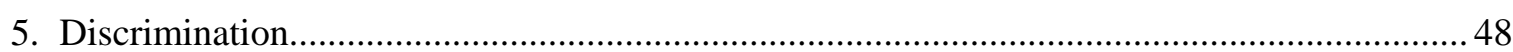

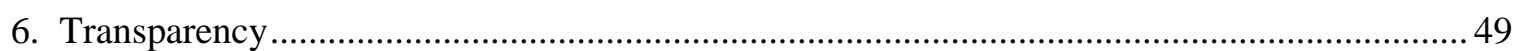

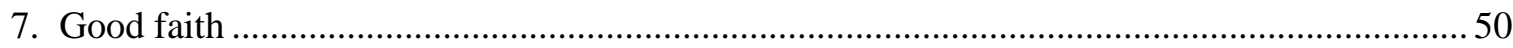

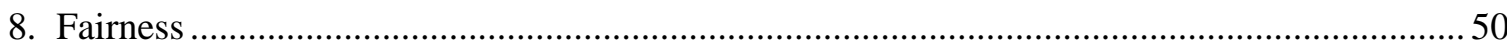


C. The substance of the NAFTA MST-FET provision is not altered by the most-favoured nation ("MFN") provision in NAFTA

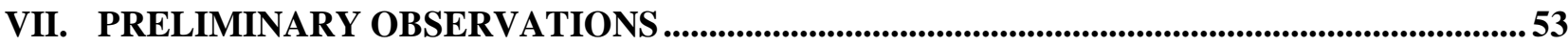

A. Differences between FET as seen by ISDS commentators and tribunals and MST-FET as seen by NAFTA governments.

1. The Alleged FET Lists of commentators and tribunals differ sharply from the view of MST-FET of the NAFTA governments...

2. Given the different content of MST-FET as seen by at least some major governments and FET as seen by tribunals, the arbitral decisions that suggest that MST-FET and autonomous FET have the same content are puzzling...

B. NAFTA government success in claim outcomes and in obtaining tribunals' application of their interpretations of MST-FET

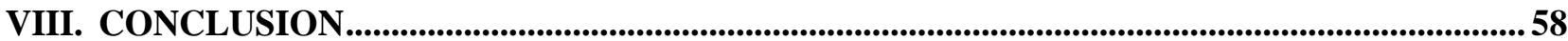

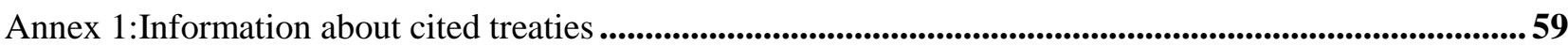

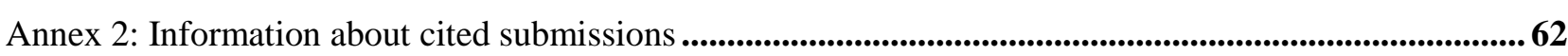




\section{EXECUTIVE SUMMARY}

As part of an ongoing work program on the balance between investor protection and the right to regulate in investment treaties, this paper engages in fact-finding on investment treaty obligations requiring governments to provide "fair and equitable treatment" (FET) to covered foreign investors. ${ }^{1}$ FET has leapt to prominence in the last 15 years as the principal ground of liability at issue in many if not most investment treaty arbitration claims. It also appears to be the substantive treaty provision most often cited in debates about the impact of investment treaties on the right to regulate.

FET is an absolute, non-contingent standard of treatment. It differs from the relative standards embodied in "national treatment" and "most favoured nation" principles which define the required treatment by reference to the treatment accorded to other investment. FET is often included as part of the protection provided to covered foreign investors in investment treaties although some recent treaties and model treaties do not refer to FET. FET clauses are of different kinds. A key distinction is between FET provisions that are limited to the minimum standard of treatment of aliens under customary international law (referred to herein as "MST-FET"), and FET clauses that are "autonomous" from the minimum standard of treatment. The first incorporates a body of external law into the treaty; the second sets an autonomous treaty standard.

Many FET clauses, especially in older treaties, are "bare" FET clauses that merely refer to fair and equitable treatment without further detail. There has been considerable debate about whether particular FET provisions, and in particular bare FET clauses, are MST-FET or autonomous provisions. A 2004 OECD working paper reported on this issue and noted that no case had been found applying a FET standard in a BIT as an autonomous standard. ${ }^{2}$ However, in a marked change, bare FET clauses in BITs are frequently seen by arbitral tribunals today as autonomous.

A finding that a clause is autonomous increases the scope for arbitral interpretation of the clause. Fairness is a broad legal principle and can give rise to the elaboration of many norms. In ISDS arbitral decisions and commentary, FET has frequently been seen as a broad and general obligation that gives rise through arbitral interpretation and analysis to extended lists of more specific rules, standards or norms in different contexts.

Recent treaty practice shows growing use of express MST-FET provisions. Examples include the PR China-Korea FTA, the recent Pacific Alliance agreement as well as in Canadian and US model BITs and treaties. This approach harkens back to the 1967 OECD Draft Convention. ${ }^{3}$ The growing use of this approach may be in part a reaction to the interpretation of autonomous FET clauses in ISDS.

MST-FET clauses are by definition expressly defined by reference to customary international law. Views about the formation of customary international law vary to some degree between different constituencies, but it is generally recognised that government action and government views about the law are the primary focus. A fact-finding focus on government action and government views on customary international law is

1 A scoping paper provides a general overview of the balance between investor protection and the right to regulate in investment treaties. See David Gaukrodger, The Balance between Investor Protection and the Right to Regulate in Investment Treaties: A Scoping Paper.

2 See OECD, "Fair and Equitable Treatment Standard in International Investment Law", OECD Working Papers on International Investment, 2004/03.

OECD, Draft Convention on the Protection of Foreign Property and Resolution of the Council of the OECD on the Draft Convention (1967). 
valuable because of this central importance and because they have rarely been considered in ISDS cases and commentary. The focus of the paper on government action and views thus reflects a new angle of approach.

The first and best known example of an MST-FET approach is the 1994 NAFTA as authoritatively interpreted by the NAFTA governments. NAFTA government views on MST-FET standard are a valuable initial reference in an examination of the balance of investor protection and the right to regulate due to extensive discussion by governments of the issues since 1994, unparalleled public access to those views and different success rates in defending claims than for governments under other FET clauses. At the same time, the limitations of NAFTA as a regional phenomenon for the study of a customary international law norm such as MST-FET are recognised.

The paper describes the views of the NAFTA governments on MST-FET both with regard to the nature of the standard and its content. The analysis is expressly devoted to presenting government views: titles and sub-titles refer to interpretations by at least one government. The views of the government are provided for information and no view is expressed about the whether any particular government view of MST-FET or customary international law is correct. Several limitations arising from the preliminary nature of the background research are noted.

With regard to the nature of the MST-FET standard, all of the NAFTA governments have interpreted the reference to customary international law to refer to law established by reference to a general and consistent practice of States that they follow from a sense of legal obligation. All of the NAFTA Parties have stated that the claimant bears the burden of establishing that the norm it invokes exists as a matter of customary international law. This requires that the claimant establish both state practice and opinio juris with regard to the proposed norm at issue. All NAFTA governments have rejected assertions that the signing of BITs with FET clauses creates customary international law. They consider that there is no opinio juris because there is no obligation to sign BITs with FET clauses; moreover, FET provisions in treaties vary widely and thus state practice lacks the necessary element of consistency.

For NAFTA governments, arbitral decisions have limited relevance to interpreting MST-FET. Arbitral interpretations of autonomous FET provisions have no relevance for the interpretation of MST-FET. Arbitral interpretations of MST-FET play a role only insofar as they have addressed state practice and opinio juris, the elements of customary international law.

NAFTA governments have also rejected the claim, advanced by claimants and some commentators and adopted by some ISDS tribunals, that the standards for autonomous FET have merged with the MST-FET standard. The NAFTA governments have stated that the customary international law can evolve. However, proof of the development of a new customary international law norm requires proof of state practice and opinio juris. Customary international law also does not evolve just because time passes and, as noted, arbitral decisions have limited relevance.

All three NAFTA governments agree that the threshold for demonstrating a violation of MST-FET is high. NAFTA governments have also emphasised that violation of domestic administrative law is insufficient to show breach of MST-FET because their domestic courts apply more demanding standards to government action than the MST. Domestic courts engaged in judicial review, which cannot award damages, can sanction behaviour that does not meet the much more demanding international standard for liability.

In terms of content of the standard, all of the NAFTA governments have recognised that the obligation not to deny justice in adjudicatory proceedings is a rule established under MST-FET. Canada and the United States have repeatedly rejected as unfounded investor claims that the MST-FET incorporates a rule protecting a foreign investor's legitimate expectations. More specifically, they have rejected claims that the 
MST-FET contains a rule providing a right to a stable legal environment. They have also rejected an alleged rule protecting investor expectations based on assurances or commitments.

While both Canada and the US exclude any rule requiring protection of legitimate expectations, they have expressed differing positions on whether an investor's expectations are even relevant as a factor to be considered in MST-FET. The United States considers that no demonstration of relevance has been made based on the two elements of customary international law. As noted above, Canada shares the general view that MST-FET rules must be demonstrated based on the two elements. However, in some contexts it has accepted that legitimate expectations based on specific commitments may be a relevant factor to be considered under certain conditions, albeit without examining state practice or opinio juris on the point.

Canada and the US have rejected claims that the MST-FET provision imposes a general obligation on States to refrain from arbitrary conduct. The Parties have noted the existence of a distinct national treatment obligation in NAFTA. They have stated that there is only limited protection from discrimination under MST-FET or alternatively that no stand-alone or independent obligation prohibiting discrimination exists under the MST-FET provision in NAFTA. All three NAFTA governments consider that regulatory transparency is not part of MST-FET. Canada and the US have rejected good faith as a stand-alone standard of MST-FET. All three governments have also rejected the view that MST-FET gives rise to a general arbitral inquiry about "fairness, equity and reasonableness".

NAFTA governments are generally strong supporters of many if not all of the principles discussed in the paper as a matter of investment policy. They have supported the inclusion of many of them in policy documents such as the OECD's Policy Framework for Investment. The narrow issue addressed in the paper is government views about their role, if any, as a basis for government liability in damages to foreign investors under customary international law under the MST-FET provision. 


\section{INTRODUCTION}

The balance between investor protection and the right to regulate is at the core of many current public debates about investment treaties and governments' treaty policy. ${ }^{5}$ A wide range of governments are recognising the importance of the issue of balance while adopting varying policy responses. This paper begins fact-finding about the balance of investor protection and the right to regulate in investment treaties. It accompanies a scoping paper that sets out a preliminary outline for analysis in this area. ${ }^{6}$

The focus here is on obligations to provide "fair and equitable treatment" (FET). FET is often included as part of the protection provided to covered foreign investors in investment treaties. It is an absolute, noncontingent standard of treatment, as opposed to the relative standards embodied in "national treatment" and "most favoured nation" principles which define the required treatment by reference to the treatment accorded to other investment. FET has leapt to prominence in the last 15 years as the principal ground of liability at issue in many if not most investment treaty arbitration claims. ${ }^{7}$ It also appears to be the substantive treaty provision most often cited in debates about the right to regulate.

FET clauses are of different kinds. A key distinction is between FET provisions that are limited to the minimum standard of treatment of aliens under customary international law (hereinafter "MST-FET" provisions), and FET clauses that are "autonomous" from the minimum standard of treatment. The first incorporates a body of external law into the treaty; the second sets an autonomous treaty standard.

$4 \quad$ This paper has been discussed by governments participating in the OECD-hosted Freedom of Investment (FOI) Roundtable. It does not necessarily reflect the views of the OECD or of the governments that participate in the Roundtable, and it should not be construed as prejudging ongoing or future negotiations or disputes pertaining to international investment agreements. The following economies are invited to participate in the Roundtable: Argentina, Australia, Austria, Belgium, Brazil, Bulgaria, Canada, Chile, People's Republic of China, Colombia, Costa Rica, Czech Republic, Denmark, Egypt, Estonia, Finland, France, Germany, Greece, Hungary, Iceland, India, Indonesia, Ireland, Israel, Italy, Japan, Jordan, Korea, Latvia, Lithuania, Luxembourg, Malaysia, Mexico, Morocco, Netherlands, New Zealand, Norway, Paraguay, Peru, Poland, Portugal, Romania, Russian Federation, Saudi Arabia, Singapore, Slovakia, Slovenia, South Africa, Spain, Sweden, Switzerland, Tunisia, Turkey, United Kingdom, United States and the European Union. Participation typically varies somewhat depending on the issues being discussed.

The bulk of the fact-finding for this paper took in the second half of 2015. Coverage of subsequent developments is more selective. A separate scoping paper provides a general overview of the balance between investor protection and the right to regulate in investment treaties. See David Gaukrodger, The Balance between Investor Protection and the Right to Regulate in Investment Treaties: A Scoping Paper.

5 As in FOI Roundtable work generally, the term investment treaties is used for convenience to refer both to stand-alone investment treaties and to investment chapters in broader treaties such as free trade agreements.

See David Gaukrodger, The Balance between Investor Protection and the Right to Regulate in Investment Treaties: A Scoping Paper. While both papers recognise that dispute resolution institutions have a significant impact the balance and the right to regulate, the papers focus primarily or wholly on substantive issues in light of other ongoing work. Government policies in this area were explored in the 2016 OECD Investment Treaty Conference on The Quest for Balance Between Investor Protection and Governments' Right to Regulate.

Issues of balance between investor protection and the right to regulate arise with regard to many other investment treaty provisions beyond FET. For example, a 2004 OECD paper examined the impact of indirect expropriation provisions on the right to regulate. See OECD, Indirect Expropriation and the Right to Regulate in International Investment Law, OECD Working Papers on International Investment, 2004/04. However, in recent years FET has outstripped indirect expropriation and other provisions as a basis for claimed and actual government liability and merits attention in the first instance. 
Categorisation of a FET clause as an MST-FET or "autonomous" provision can present difficulties. There has been considerable debate about whether particular FET provisions -- and in particular "bare" FET provisions that merely refer to fair and equitable treatment without further detail -- are limited to the customary international law minimum standard or are autonomous. In contrast to the situation as described in a 2004 OECD working paper $^{8}$, arbitral decisions since 2004 have increasingly tended to interpret FET clauses as autonomous; this expands the scope for arbitral interpretation of the clause.

Recent treaty practice shows expanding use of express MST-FET provisions in major treaties around the world. MST-FET provisions appear to be an important element of governments' efforts to address the balance between investor protection and the right to regulate. Available statistics suggest that governments have generally had greater success defending claims under MST-FET provisions than under FET provisions that are interpreted as being autonomous.

In light of its growing importance, this paper begins to examine MST-FET. It focuses primarily on government action and views about MST-FET. This government-focused approach builds on prior Roundtable interest and work on the ongoing debate about the respective roles of governments and arbitral tribunals in treaty interpretation. Government materials merit attention because they have been rarely examined in general ISDS commentary focused primarily on arbitral cases.

A focus on governmental action in this area is also valuable because there is now a fundamental debate about the relative role that government action and views on the one hand, and arbitral interpretations, on the other hand, play in defining the applicable standards under MST-FET. It is generally recognised, at least as a matter of principle, that customary international law (of which MST-FET is a part) is based at least primarily on the behaviour and views of states - their state practice and opinio juris. ${ }^{9}$ As discussed below, some governments have forcefully stated that state practice and opinio juris are the exclusive basis for derivation of new rules under MST/FET. ISDS tribunals, however, have generally demonstrated a strong preference for arbitral precedent and a marked reluctance to engage with state practice or opinio juris in relation to MST/FET.

The content of the MST-FET standard appears to be discernibly related to how -- and by whom -- the standard is defined. It is equally the subject of increasingly sharp differences of views. As outlined below, a number of governments have stated that the content of MST-FET is very limited and that a high threshold of proof for customary international law must be met for any additional asserted rules. These views contrast with views in ISDS cases and commentary that have been seen as generating a lengthy list of norms that are alleged to form part of the FET or MST/FET standard. There has been a tendency in some cases to conflate the MST-FET and autonomous standards, particularly where little or no reference is made to state practice or opinio juris for either standard. Investors frequently invoke alleged FET norms in cases under MST-FET although they rarely if ever provide evidence of state practice or opinio juris in support of such claims.

The balance of the paper sets forth factual findings with regard to government action in this area in more detail. A first background section reviews the distinction between MST-FET clauses and autonomous FET clauses, as discussed notably in the 2004 working paper for the OECD Investment Committee, and some general developments since 2004 concerning FET clauses. A second section examines the growing See OECD, “Fair and Equitable Treatment Standard in International Investment Law”, OECD Working
Papers on International Investment, 2004/03 ("2004 FET paper").

As discussed further below, opinio juris is generally considered to refer to the sense of legal obligation that must accompany general and consistent State practice in order to generate a customary international law norm. 
importance of express MST-FET clauses in recent treaty practice and the general importance of studying government action and government views in identifying customary international law norms.

The third, fourth and fifth sections turn to the NAFTA context. The third section outlines the rationale for an initial focus on NAFTA governments' action, including different and higher success rates in defending claims, extensive discussion by governments of the issues since 1994 and unparalleled public access to those views. The limitations of NAFTA as a regional phenomenon for the study of a customary international law norm such as MST-FET are recognised. ${ }^{10}$

The fourth section outlines views of the NAFTA governments about the nature of the MST-FET standard and how it is identified. The fifth section then turns to their views about the content of MST-FET. A final section notes that the preliminary analysis appears to reveal several profound differences between NAFTA governments' views and the views of many ISDS tribunals and commentators about the nature of MSTFET, how it is identified and its content.

\section{FAIR AND EQUITABLE TREATMENT (FET) PROVISIONS IN INVESTMENT TREATIES}

The OECD Investment Committee last examined FET clauses in detail in 2004. There has been significant evolution since then in a number of areas. This section provides a preliminary overview of some key aspects of that evolution.

A. "Bare" FET clauses in BITs are frequently seen by arbitral tribunals today as autonomous
from customary international law, a marked change from the situation as seen at the OECD in 2004

It appears that many FET claims are resolved today under what are seen to be "autonomous" versions of FET that are not limited to the MST under customary international law. This is a recent and remarkable development. The 2004 OECD analysis of FET for the Investment Committee noted that "[n]o case ha[d] been found that applied the "fair and equitable treatment" standard of a bilateral investment treaty as an autonomous standard". ${ }^{11}$

The 2004 FET paper recalled that intensive discussions started in the OECD Investment Committee ${ }^{12}$ in the early 1960s and culminated in the adoption of the Draft Convention on the Protection of Foreign Property by the OECD Council on 12 October 1967 ("OECD Draft Convention"). ${ }^{13}$ It noted that the OECD Draft Convention, although never opened for signature, represented the collective view and dominant trend of OECD countries on investment issues and influenced the pattern of deliberations on foreign investment in that period.

\footnotetext{
10 Future work is expected to extend to additional government action and views relating to MST-FET and FET, as well of the views of others.

2004 FET paper, p. 23.

12 The Investment Committee was then known as the Committee on International Investment and Multinational Enterprises. For convenience, both are referred to herein as the Investment Committee.

13

Id. pp. 4,10 .
} 
The Draft Convention contains a guarantee of fair and equitable treatment. It is a "bare" clause that simply refers to an obligation to provide fair and equitable treatment without further specification. Under the heading "Treatment of Foreign Property", Article 1 (a) states that "Each Party shall at all times ensure fair and equitable treatment to the property of the nationals of the other Parties...".

The text of the FET provision does not refer to customary international law or expressly tie FET to the MST. However, in the Notes and Comments to Article 1 of the Draft Convention, the Investment Committee clarified that the standard required under FET conforms in effect to the "minimum standard" which forms part of customary international law:

The phrase "fair and equitable treatment", customary in relevant bilateral agreements, indicates the standard set by international law for the treatment due by each State with regard to the property of foreign nationals. The standard requires that - subject to essential security interests - protection afforded under the Convention shall be that generally accorded by the Party concerned to its own nationals, but, being set by international law, the standard may be more exacting where rules of national law or national administrative practices fall short of the requirements of international law. The standard required conforms in effect to the "minimum standard" which forms part of customary international law. ${ }^{14}$

The 2004 FET paper noted evidence of concordant views about FET conforming to the minimum standard in the state practice of some countries such as Switzerland and the United States. ${ }^{15}$ It also noted a number of cases to similar effect.

The decision, after intensive work, not to refer expressly in the MST in the Draft Convention text but to expressly clarify that FET conformed to the MST in accompanying notes by the Investment Committee is of interest. It may have been related to efforts to avoid the substantial controversy at the time about the notion of a MST. ${ }^{16}$

The 2004 FET paper noted that the influence of the OECD Draft Convention was obvious in the growing number of bilateral investment treaties that were negotiated between developed and developing countries beginning in the late 1960s and that referred to FET. The 2004 paper also noted subsequent arguments by some commentators that the FET clause should be seen not as limited to the MST, but as an autonomous provision. It noted the central position of a 1982 article by F.A. Mann in what was then referred to as a dissident view:

Dr. Mann, who wrote primarily with reference to UK Bilateral Investment

Treaties, is widely cited as the main dissident voice by most of the

14 OECD, Draft Convention on the Protection of Foreign Property and Resolution of the Council of the OECD on the Draft Convention (1967), Notes and Comments to Art. 1, para 4(a).

See 2004 FET paper, pp. 10 n.40, 11 n.47.

16

See 2004 FET paper, p. $8 \mathrm{n} .33$ ("In the past, the existence of an international minimum standard for the treatment of alien-owned property and investments has been repeatedly challenged. During most of the last century, it has been the object of tension between developed and developing countries, with several countries challenging the existence (or persistence) of a customary norm of an international minimum standard. This tension had implications in several sectors, for example the League of Nations and the UN International Law Commission was unable to reach agreement on a codification of the law of State responsibility for injury to aliens.") 
commentators who wrote on this issue. In his view, the proposition that investments shall have fair and equitable treatment and full protection and security constitutes the "overriding obligation". ... Mann goes on to say that it is misleading to equate the fair and equitable with the minimum standard: this is because "the terms 'fair and equitable treatment' envisage conduct which goes far beyond the minimum standard and afford protection to a greater extent and according to a much more objective standard than any previously employed form of words. A tribunal would not be concerned with a minimum, maximum or average standard. It will have to decide whether in all circumstances the conduct in issue is fair and equitable or unfair and inequitable. No standard defined by other words is likely to be material. The terms are to be understood and applied independently and autonomously". ${ }^{17}$

The 2004 FET paper also noted some arbitration cases that were beginning to elaborate interpretations of FET as autonomous from customary international law, sometimes by reference to Mann's 1982 article. These included a few NAFTA cases, but these had been expressly rejected on this point by the binding 2001 Joint Interpretation by the three NAFTA parties. ${ }^{18}$ The paper also referred to the then-recent Tecmed decision which, it noted, mentioned an autonomous approach as one of the alternative approaches but that went on to judge the claim against the international law principle of good faith. ${ }^{19}$ The paper noted that differently-worded FET clauses could be interpreted differently and that depending on the parties' intent, some could be interpreted as extending beyond customary international law.

As noted above, the 2004 FET paper noted that no case had been found applying a FET standard in a BIT as an autonomous standard. The situation is different today. It appears that many "bare" FET clauses that merely state the principle of fair and equitable treatment, as does art. 1(a) of the OECD Draft Convention, are today generally interpreted by arbitral tribunals as establishing an autonomous FET standard. ${ }^{20}$ The

17 See 2004 FET paper, p. 24 (citing F.A. Mann, “The Legal Aspects of Money” (1982) p. 510, as quoted by J.C. Thomas in "Reflection on Article 1105 of NAFTA: History, State Practice and the Influence of Commentators", ICSID Review - Foreign Investment Law Journal (2002) 17 (1) pp. 21-101, p. 58.).

The 2004 FET paper noted that Mann expressed a different and far less expansive view of FET in a treatise published the following year. See 2004 FET paper, p. 24, quoting F.A. Mann, "The Legal Aspects of Money" (1982) p. 510, as quoted by J.C. Thomas op. cit., p.58. ("In some cases, it is true, treaties merely repeat, perhaps in slightly different language, what in essence is a duty imposed by customary international law; the foremost example is the familiar provision whereby states undertake to accord fair and equitable treatment to each other's nationals and which in law is unlikely to amount to more than a confirmation of the obligation to act in good faith, or to refrain from abuse or arbitrariness").

See NAFTA Free Trade Commission, Notes of Interpretation of Certain Chapter Eleven Provisions (31 July 2001).

2004 FET paper, p. 23; Técnicas Medioambientales Techmed S.A. v. the United Mexican States, ICSID, Award (29 May 2003).

See Patrick Dumberry, The Fair and Equitable Treatment Standard: A Guide to NAFTA Case Law on Article 1105 (Kluwer 2013) (hereinafter "Dumberry 2013"), p. 307 ("the vast majority of non-NAFTA tribunals have interpreted an 'unqualified' FET clause as having a distinct and separate meaning from the minimum standard of treatment.") 
view by many arbitral tribunals that FET clauses today are autonomous from the MST appears to constitute a significant evolution from the 2004 situation. ${ }^{21}$

As described below, there is a trend to adopt clauses in new treaties that expressly limit FET to the MST. ${ }^{22}$ This may be in part a reaction to the interpretation of FET clauses in ISDS.

\section{B. A determination that a FET clause is autonomous increases the scope for arbitral interpretation of the clause}

As discussed further below, customary international law is often understood to refer to law established by reference to a general and consistent practice of States that they follow from a sense of legal obligation. Development of new norms of customary international law is often considered to be a slow process. This can mean that it would be expected that the content of a FET clause limited to norms generated in customary international law is unlikely to evolve and develop rapidly.

In contrast, where a treaty FET provision is seen as establishing an autonomous obligation of fairness unconnected to customary international law, it may be seen as an invitation to elaborate a series of rules to ensure fairness in different contexts. A number of ISDS commentators have described autonomous FET provisions in these terms. For example, Charles H. Brower II has described the FET clause as an "intentionally vague term, designed to give adjudicators a quasi-legislative authority to articulate a variety of rules necessary to achieve the treaty's object and purpose in particular disputes". ${ }^{23}$ As noted by Dumberry, Stephan Schill has described autonomous FET clauses as an example of a "'fundamental shift in power from States to arbitral tribunals' whereby 'substantial rule making power' has, in effect, been transferred to tribunals whose 'function is not restricted to applying pre-existing rules and principles to the facts of a case, but extends to developing the existing principles into more precise rules and standards of conduct"'. ${ }^{24}$

In most ISDS cases and commentary, prior arbitral cases appear to have been in practice the primary source used to define the contents of autonomous FET clauses although more research is necessary. In addition to arbitral precedents, the inquiry has been described as being guided generally by other considerations including the plain meaning of the words, treaty preambles, State practice regardless of whether it is followed out of a sense of legal obligation, or other sources of international law. Numerous principles, often apparently borrowed from domestic constitutional or administrative law, have been proposed or used to guide the inquiry under FET. These include standards of review, proportionality analysis and other approaches. ${ }^{25}$

21 The 2004 FET paper also noted a third interpretation under which FET is limited not to the MST under customary international law, but to international law generally, including other international law sources, such as general principles of law or applicable treaties. 2004 FET paper, p. 20.

22 This paper expresses no view about how or whether bare (or other) FET clauses relate to the MST.

23 See Charles H. Brower II, Structure, Legitimacy, and NAFTA's Investment Chapter, 36 Vand. J. Transnat'l L. 37, 66 n.163 (2003).

Dumberry 2013, p. 128 (quoting S. Schill, The Multilateralization of International Investment Law 275 (2009).

See the discussion on standard of review in David Gaukrodger, The Balance between Investor Protection and the Right to Regulate in Investment Treaties, pp. 28-30. 


\section{The growth of FET claims and of the list of norms allegedly included in FET}

FET is today the provision most frequently invoked by investor claimants and the most frequent basis for damages awards. FET has emerged as "the most relied upon and successful basis for [investment treaty] claims by investors". ${ }^{26}$

Fairness is a broad legal principle and can give rise to the elaboration of many norms. Claimants, cases and ISDS commentary have generated lists of norms that have been asserted to be enveloped within FET provisions. These are occasionally referred to by commentators as a "shopping list" and the various alleged rules are frequently advanced by investors under separate headings in ISDS cases. Many of the norms have been applied by tribunals in at least some cases. In turn, a number of ISDS commentators have concluded that many rules are included in FET, based principally on arbitral interpretations. A 2014 article on the "current contours" of FET is illustrative of this approach:

No one will doubt the inherent breadth of the terms fair and equitable which are in practice understood together as one concept. At the same time, it will also be recognized that arbitral jurisprudence has succeeded enough to unfold the concept in a casuistic manner leading to groups and clusters of subgroups with more defined contours. My own count of these, leads me to these clusters, with some overlap: good faith in the conduct of a party, consistency of conduct, transparency of rules, recognition of the scope and purpose of laws, due process, prohibition of harassment, a reasonable degree of stability and predictability of the legal system, and, in particular, recognition of the legitimate expectation on the part of the investor to which I will turn later. I consider that arbitrariness and discrimination also fall under the heading of FET, even though separate, specific rules in investment treaties may (or may not) address these concepts. ${ }^{27}$

Using a similar approach, Stephan Schill has identified "seven specific normative principles" that he sees as elements of the FET standard as considered by tribunals: (1) the requirement of stability, predictability and consistency of the legal framework; (2) the principle of legality; (3) the protection of investor confidence or legitimate expectations; (4) procedural due process and denial of justice; (5) substantive due process or protection against discrimination and arbitrariness; (6) the requirement of transparency; and (7) the requirement of reasonableness and proportionality. ${ }^{28}$ Tribunals have also set forth some similar lists of norms that they see as part of the FET standard. ${ }^{29}$ For convenience, these types of lists are referred to collectively below as "Alleged FET Lists".

UNCTAD, Fair and Equitable Treatment, UNCTAD Series on Issues in International Investment Agreements II (2012), p. 1.

Rudolf Dolzer, Fair and Equitable Treatment: Today's Contours, 12 Santa Clara J. Int'l L. 7 (2014), p. 15. See Dumberry 2013, p. 131 ("Another notable feature of the literature on the FET is the tendency of scholars to offer (based on their reviews of relevant case law) a list of the different 'elements' of which the standard is said to be comprised.")

Stephan Schill, Fair and Equitable Treatment as an Embodiment of the Rule of Law, in The International Convention on the Settlement of Investment Disputes (ICSID): Taking Stock after 40 Years 79-80 (R. Hofmann \& C. Tams eds., Nomos 2007), cited in Dumberry 2013, p. 133-34 \& n.32.

See, e.g., Biwater Gauff (Tanzania) Ltd v. Tanzania, Award and Concurring and Dissenting Opinion, (24 July 2008) $§ 602$ (finding that the separate components relevant to the dispute at issue were the protection of legitimate expectations; good faith; and transparency, consistency and non-discrimination); Rumeli 
The breadth of the fairness principle and the development of individual norms under autonomous FET as applied by tribunals have led to suggestions that it overlaps with more specific provisions in treaties. ${ }^{30}$ This has been a notable development, for example, with regard to indirect expropriation. Claims for indirect expropriation are frequently accompanied where possible by a FET claim for the same damages. Treaties rarely define expressly the applicable remedies for breaches of FET ${ }^{31}$ ISDS tribunals have frequently equated the approach to calculating damages for indirect expropriation and FET claims. ${ }^{32}$

It is often considered that indirect expropriation requires a very substantial impact of government regulation on the investment, one that is tantamount to a direct expropriation. This is a considerable hurdle for claimants. Many claims of indirect expropriation may fail based on an insufficient impact. ${ }^{33}$ In contrast, there is generally no explicit threshold of impact for a FET claim. Any amount of damage caused by conduct that is contrary to FET can in theory give rise to a claim by a covered foreign investor. ${ }^{34}$

\section{A number of ISDS tribunals have found that there is little or no distinction between autonomous FET and FET that is limited to the minimum standard of treatment under customary international law (MST-FET)}

A further development arising out of the many FET claims since 2004 are arbitral decisions addressing the question whether the rules under what is seen as an autonomous FET provision are the same or different

Telekom A.S. and Telsim Mobil Telekomunikasyon Hizmetleri A.S. v. Kazakhstan, Award, (29 July 2008) § 609 (transparency, good faith, the State's conduct cannot be arbitrary, grossly unfair, unjust, idiosyncratic, discriminatory, or lacking in due process; the State must respect procedural propriety and due process; and protection of the investor's reasonable and legitimate expectations). For a variety of other versions of the list by other commentators and in arbitral decisions, see Dumberry 2013, pp. 130-35.

See also Rudolf Dolzer, Fair and Equitable Treatment: Today's Contours, 12 Santa Clara J. Int'1 L. 7 (2014) p. 15 (suggesting that arbitrariness and discrimination fall under the heading of FET, "even though separate, specific rules in investment treaties may (or may not) address these concepts").

David Gaukrodger \& Kathryn Gordon (2012), “Investor-State Dispute Settlement: A Scoping Paper for the Investment Policy Community”, OECD Working Papers on International Investment, 2012/03, p. 29.

See, e.g., Sempra Energy International v. Argentine Republic, ICSID, Award, 28 September $2007 \S 403$ ("[a]lthough there is some discussion about the appropriate standard applicable in such a situation, several awards of arbitral tribunals dealing with similar treaty clauses have considered that compensation is the appropriate standard of reparation in respect of breaches other than expropriation, particularly if such breaches cause significant disruption to the investment made. In such cases it might be very difficult to distinguish the breach of fair and equitable treatment from indirect expropriation or other forms of taking and it is thus reasonable that the standard of reparation might be the same."); Enron Creditors Recovery Corporation (formerly Enron Corporation) and Ponderosa Assets, L.P. v. Argentine Republic, ICSID, Award, 22 May $2007 \S 363$ ("the line separating indirect expropriation from the breach of fair and equitable treatment can be rather thin and in those circumstances the standard of compensation can also be similar on one or the other side of the line").

Occidental Exploration and Production Company v. The Republic of Ecuador, LCIA Case No. UN3467, Award, 1 July 2004, § 89; CMS Gas Transmission Company v. The Republic of Argentina, ICSID Case No. ARB/01/8, Award, 12 May 2005, §§ 262-263.

For cases where the tribunal found no (indirect) expropriation, but a violation of FET, see: Emilio Agustín Maffezini v. The Kingdom of Spain, ICSID Case No. ARB/97/7, Award, 13 November 2000; MTD Equity Sdn. Bhd. and MTD Chile S.A. v. Republic of Chile, ICSID Case No. ARB/01/7 , Award, 25 May 2004; Occidental Exploration and Production Company v. The Republic of Ecuador, LCIA Case No. UN3467, Award, 1 July 2004; Cargill, Incorporated v. United Mexican States, ICSID Case No. ARB(AF)/05/2, Award, 18 September 2009. 
from those applicable under the customary international law standard of MST-FET. This issue involves the question whether the various rules in an Alleged FET List are included in MST-FET.

Tribunals have answered this question in different ways and more research is required. However, it appears that a number of tribunals have considered that autonomous FET and MST-FET standards are the same. ${ }^{35}$ These views, however, appear to be rarely based on significant analysis of government action and views (state practice and opinio juris). Instead, they appear to be based primarily on a comparison of arbitral and commentator views about FET and arbitrator and commentator views about MST-FET. This approach may explain in some cases the tendency to find that the two norms are similar. As described below, however, it is generally accepted that it is at the very least important to consider available state practice and opinio juris in identifying customary international law norms like MST-FET.

Analysis of government actions and views in the present paper and additional work should allow a more informed analysis by governments and others of the similarities and differences between autonomous FET provisions (typically interpreted to include a number of rules in the Alleged FET Lists) and MST-FET.

\section{E. FET has become an important component of debates about the impact of treaties on regulation}

The centrality of FET to high-profile ISDS claims and awards and its encompassing of multiple rules in the view of many tribunals and commentators has contributed to it becoming a subject of attention in the debate about the impact of investment treaties on regulation.

A number of NGOs have sharply criticised the FET provision. For example, the Corporate Europe Observatory has criticised what it describes as "far-reaching protections of private property enshrined in catch-all clauses [in investment treaties] such as 'fair and equitable treatment' and 'protection from indirect expropriation'. The trouble is that these clauses have been interpreted so broadly that they gave a carte blanche to corporations to sue states for any regulations that could be deemed to affect current or future profits." ${ }^{36}$

Recently, FET has also been seen by some strong advocates for free trade agreements as a provision that undermines public support for free trade. They see the clause as the epitome of the type of broad provision that creative lawyers can seek to exploit to develop new norms. In their view, making this type of vague clause available only to covered foreign investors erodes public support for free trade agreements by contributing to a perception that those agreements are a "corporate handout":

The "fair and equitable" treatment obligation is well-known as a general "catch-all" provision for government actions that harm companies. But to what degree do investors actually face treatment that is not "fair" or "equitable"? And what kind of treatment is this exactly? A few anecdotes

35 See, e.g., Deutsche Bank AG v. Democratic Socialist Republic of Sri Lanka, Award, 31 October 2012, §§ 418-419 ("the actual content of the Treaty standard of fair and equitable treatment is not materially different from the content of the minimum standard of treatment in customary international law, as recognised by numerous arbitral tribunals and commentators."); SAUR International SA v. Republic of Argentina, Decision on Jurisdiction and Liability, §§ 491-494. Other tribunals have found that autonomous FET and MST-FET have different content.

Cecilia Olivet \& Pia Eberhardt, Profiting from Crisis: How corporations and lawyers are scavenging profits from Europe's crisis countries (Corporate Europe Observatory, March 2014), p. 6; see also Lori Wallach, "Fair and Equitable Treatment" and Investors' Reasonable Expectations: Rulings in U.S. FTAs \& BITs Demonstrate FET Definition Must be Narrowed, Global Trade Watch (5 September 2012); and Nathalie Bernasconi-Osterwalder \& Rhea Tamara Hoffmann (2013), The German Nuclear Phase-Out Put to the Test in International Investment Arbitration? Background to the new dispute Vattenfall v. Germany (II). 
aside, we have a very limited understanding. The result has been an explosion of litigation as creative lawyers seek to push the boundaries of the obligation. ...

International judicial review is not objectionable in and of itself, of course. But the nature of the obligations, who has access to them, and how enforceable they are need to be considered carefully, and the legal obligations must be written precisely. Having open-ended provisions that are available only to foreign investors contributes to the perception that international economic law is a corporate handout, with ordinary people ignored. Depending on how the courts later rule, that perception may become a reality. ${ }^{37}$

Critics complain, for example, that some versions of FET can be used to challenge non-discriminatory measures for a public purpose. More research is required, but it appears that general non-discriminatory regulatory measures have been at issue in a number of high-profile ISDS claims based on FET.

In contrast, some legal commentators see the FET provision as having little or no impact on the right to regulate due to what they see as a very narrow interpretation of key provisions such as FET:

The same protection of the "right to regulate" has been applied [to] the concept of fair and equitable treatment, a touchstone of international investment law. Although a seemingly vague concept, fair and equitable treatment has been interpreted by arbitral panels very narrowly to only include a violation of an investor's fundamental rights or a denial of justice. Fair and equitable treatment obliges states to accord basic substantive and procedural rights pursuant to the rule of law. Investors are entitled to a stable and predictable legal framework, consistent decisionmaking by the host state, procedural due process, protection against discrimination and arbitrariness, and transparency in dealing with the host government. $^{38}$

Partly in response to the growing debate, FET has become a key area for interest in treaty innovation. It is increasingly the subject of different formulations in treaties, in part in response to the outcomes and interpretations in some cases. A key development is the growth of FET provisions expressly limited to the MST. This type of clause, often seen as being inspired by the 1994 NAFTA agreement and its subsequent binding interpretation on the matter, is also aligned with the meaning of the FET clause in the OECD Draft Convention as explained by the Investment Committee.

Simon Lester, Does Investor-State Dispute Settlement Need Reform?, Cato Unbound (11 May 2015). See also Dan Ikenson, A Compromise to Advance the Trade Agenda: Purge Negotiations of Investor-State Dispute Settlement, Cato Institute Free Trade Bulletin No. 57 (4 March 2014) ("ISDS is ripe for exploitation by creative lawyers. There is a lot of latitude for interpretation of what constitutes "fair and equitable" treatment of foreign investment, given the vagueness of the terms and the uneven jurisprudence. Thus, ISDS lends itself to the creativity of lawyers ...... Among the complaints worldwide in 2012 were challenges related to 'revocations of licenses, breaches of investment contracts, irregularities in public tenders, changes to domestic regulatory frameworks, withdrawals of previously granted subsidies, direct expropriations of investments, tax measures and others."') (footnote omitted).

Christian Tietje \& Freya Baetens, The Impact of Investor-State-Dispute Settlement (ISDS) in the Transatlantic Trade and Investment Partnership $§ 109$ (study prepared for Minister for Foreign Trade and Development Cooperation, Ministry of Foreign Affairs, The Netherlands), available on the Ministry website. 


\title{
III. FET PROVISIONS LIMITED TO THE MINIMUM STANDARD OF TREATMENT UNDER CUSTOMARY INTERNATIONAL LAW ("MST-FET PROVISIONS") HAVE GROWING RELEVANCE
}

\author{
A. Governments have included express MST-FET provisions in a growing range of treaties \\ between major economies
}

The treaty model limiting FET to the MST under customary international law is growing in influence in all regions. Since its inclusion in the 1994 NAFTA $^{39}$ it has tended to be a consistent practice of the NAFTA Parties in their treaties, as noted below. It has been incorporated into the treaty practice of a wide range of governments particularly in recent treaties. It is included in the recently concluded Transpacific Partnership Agreement (TPP), signed on 4 February 2016.

Numerous other major recent treaties in Asia and the Pacific have limited FET to the MST. These include the China-Korea FTA, art. 12.5 \& Annex A; Singapore-US FTA, art. 15(5); Australia-Korea FTA, art. 14.5; Canada-China BIT, art. 4; Japan-Mongolia EPA, art. 10.5; Korea-US FTA art. 11(5) \& Annex 11-A; and the Japan-Philippines EPA, art. 91.

ASEAN investment agreements with major economies including India and Korea have similarly expressly provided that FET provides no greater rights than under the MST under customary international law. ${ }^{40}$ Some ASEAN treaties with other countries combine a clarification limiting FET to customary international law with a reference to FET applying to claims of denial of justice (a widely-recognised rule under the MST).$^{41}$ Other ASEAN agreements directly limit FET to claims of denial of justice. ${ }^{42}$

Recent prominent examples of limiting FET to the MST in the Americas include art. 10.6 of the Additional Protocol to the Pacific Alliance agreement between Chile, Colombia, Mexico and Peru, which entered into

39

For convenience, treaties are generally referred to by short titles with the parties listed in alphabetical order and an indication of whether the treaty is a stand-alone investment treaty (BIT) or a broader agreement (FTA). Annex 1 provides the full names and dates of cited treaties.

ASEAN-Korea Investment Agreement, art. 5; ASEAN-India Investment Agreement, art. 7. The ASEANIndia treaty appears to specify that Indonesia is not subject to the specific clarification that the FET provision provides no greater rights than the MST under customary international law. See footnote to art. 7(2). A similar reference to Indonesia is made in AANZFTA, art. 6. The purpose and effect of these provisions for Indonesia is not clear.

AANZFTA, Article 6 ("Art. 6(1) Each Party shall accord to covered investments fair and equitable treatment and full protection and security. Art. 6(2) For greater certainty (a) fair and equitable treatment requires each Party not to deny justice in any legal or administrative proceedings. ....; (c) the concepts of "fair and equitable treatment" and "full protection and security" do not require treatment in addition to or beyond that which is required under customary international law, and do not create additional substantive rights.

The ASEAN-China Investment Agreement (art.7(2)(a)) directly limits FET to cases of denial of justice without referring to customary international law, stating that FET "refers to the obligation to each Party not to deny justice in any legal or administrative proceedings". The 2009 ACIA investment treaty between the 10 ASEAN members also may limit FET to claims of denial of justice without referring to the MST or customary international law. It provides that fair and equitable treatment "requires each Member State not to deny justice in any legal or administrative proceedings in accordance with the principle of due process..." ACIA, art. 11(2). 
force in July 2015 $5^{43}$; Central America-Dominican Republic FTA (CAFTA-DR) (Costa Rica, Dominican Republic, El Salvador, Guatemala, Honduras, Nicaragua, and the United States); the Central AmericaMexico FTA art. 11.3 (Costa Rica, El Salvador, Guatemala, Honduras, Mexico, Nicaragua); Peru-US FTA, art. 10.5; Mexico-Panama FTA, art. 10.5.; Mexico-Peru FTA, art. 11.06.

As noted above, countries that regularly use MST-FET provisions, including the NAFTA and other governments, have included them in recent treaties with major partners across the world. As the result, the provision now figures in many recent cross-regional treaties. For example, the limitation is included in the Oman-US FTA, art. 11.5 \& Annex 11-A, and the Chile-Japan FTA, art. 75. It is regularly included in Mexico's recent treaties such as India-Mexico BIT, art. 5; Mexico-UK BIT, art. 3; Mexico-Singapore BIT, art. 4; Japan-Mexico FTA, art. $60 .^{44}$ It is also regularly included in Canada's treaties, such as CanadaKuwait BIT, art. 6, and in Chile's recent FTAs, such as Chile-Japan FTA, art. 75. The limitation is included in the 2012 US Model BIT and the Canada 2004 Model BIT.

Penetration of the FET-MST model in Africa appears to be more sporadic although more research is necessary. Examples include Canada-Nigeria BIT, art. 6; Burkina Faso-Canada BIT, art. 6; Canada-Côte d'Ivoire BIT, art. 6; and Canada-Mali BIT, art. 6. Some examples of similar approaches also exist. ${ }^{45}$

European treaty practice appears to be more fluid. The treaty practice of Western EU member states has generally not included an express limitation, with a few exceptions, such as the Mexico-UK BIT, art. 3. However, the Lisbon Treaty transferred competence over foreign direct investment (FDI) from the EU member states to the EU. ${ }^{46}$ In 2011, a European Parliament resolution on investment policy stated that future EU investment treaties should define FET by reference to the level of treatment established by customary international law. ${ }^{47}$ Under other amendments to the EU treaties by the Lisbon Treaty, the Parliament must now approve EU investment treaties before they are concluded and it has become an active participant in EU debates over treaty policy. ${ }^{48}$

The publicly-available EU treaties that exist at present adopt different approaches to defining FET. See CETA, art. 8.10; EU-Singapore FTA, art. 9.4. However, neither treaty expressly limits FET to MST-FET and each adopts a different approach to FET. ${ }^{49}$

43 Protocolo Adicional al Acuerdo Marco de la Alianza del Pacífico (10 Feb. 2014).

44 See also Exchange of Notes on the negotiation of an agreement on investment between Hong Kong, China and Mexico (7 Sept. 2012) ("The negotiation on the Investment Agreement shall cover, inter alia, the following elements governing investment between the Parties: ... according investments a minimum standard of treatment in accordance with customary international law ...").

Nigeria-Turkey BIT, art. 4 ("in accordance with international law minimum standard of treatment, including fair and equitable treatment and full protection and security”); Egypt-Mauritius BIT, art. 4.

Treaty on the Functioning of the European Union, arts. 3, 206, and 207(1).

See European Parliament Resolution on the Future European International Investment Policy, 6 April 2011, $\S 19$ [FET should be "defined on the basis of the level of treatment established by international customary law".]

Treaty on the Functioning of the European Union, arts. 207(3) and 218, in particular 218(6).

Canada agreed in CETA to a list of elements rather than an express reference to the MST under customary international law in the particular context of negotiations with the EU. Apart from the context of particular negotiations, however, Canada's recent treaties suggest that its general policy to use MST-FET remains unchanged. See Burkina Faso-Canada BIT (signed 20 April 2015), art. 6 (providing covered investments "treatment in accordance with the customary international law minimum standard of treatment of aliens, including fair and equitable treatment and full protection and security" and clarifying that the concept of 
Some views have evolved during the negotiation of CETA in the context of the recent debate and evolution of public opinion over treaty policy in the EU and elsewhere. A draft CETA text (including its FET provision not expressly tied to customary international law) was a basis for the European Commission consultation on the investment provisions of TTIP. Strong public opposition to the proposed policy led to further review of the EU's investment policy with the protection of the right to regulate as one of the four core issues being addressed. An explicit reference to the right to regulate was subsequently added to the core text of CETA. ${ }^{50}$ A provision was also added to clarify that regulation or modification to laws which negatively affects an investment or interferes with an investor's expectations, is not alone sufficient to breach an obligation under the investment chapter. ${ }^{51}$ In addition to changes to the text of the treaty, a joint interpretation agreed between Canada and the EU and its Member States contemporaneously with the signing of CETA further states that "CETA will not result in foreign investors being treated more favourably than domestic investors". 52

\section{B. At least until its content is stabilised, intense investor and tribunal attention to FET likely mean that MST-FET will frequently be subject to interpretation by governments and applied by tribunals}

The expanded use of express MST-FET clauses in major treaties is an important development. It suggests movement, albeit modest, towards an expressly common provision on what has been the most-used provision in recent ISDS cases. It also incorporates a body of law outside the treaty into the treaty. Customary international law and the minimum standard are not established by the treaty; rather the treaty incorporates an external standard. This makes the FET/MST provisions fundamentally different from provisions that set autonomous treaty standards.

fair and equitable treatment does "not require treatment in addition to or beyond that which is required by the customary international law minimum standard of treatment of aliens"); Canada-Côte d'Ivoire FIPA (30 Nov. 2014), art. 6; Canada-Mali (28 Nov. 2014), art. 6.

Early in the CETA negotiations, there were reportedly concerns among some EU member states that CETA could lead to excessive NAFTA influence on EU investment policy. See, e.g., August Reinisch, The EU on the Investment Path - Quo Vadis Europe? The Future of EU BITs and other Investment Agreements, 12 Santa Clara J. Int'l L. 111 (2014), p. 123 ("As regards the level of detail, the instructions [in the Council Negotiating Directives of 12 September 2011 concerning the negotiations with Canada, India and Singapore appear to favour the traditional European approach by adhering to a rather concise treaty text, without clarifications limiting the scope of FET and indirect expropriation as they are known from US and Canadian BITs as well as NAFTA. In fact, avoidance of "NAFTA-contamination" was reportedly a specific wish of some Member State officials.") (footnotes omitted). See Matthew Porterfield, $\underline{A}$ Distinction Without a Difference? The Interpretation of Fair and Equitable Treatment Under Customary International Law by Investment Tribunals, IISD (22 March 2013) (reporting alleged concern in EU that use in CETA of MST-FET as in NAFTA could significantly reduce the level or protection for investment afforded by the FET standard). As noted in the text, views have evolved significantly since the early negotiations.

CETA, art. 8.9.

See CETA, art. 8.9(2) ("For greater certainty, the mere fact that a Party regulates, including through a modification to its laws, in a manner which negatively affects an investment or interferes with an investor's expectations, including its expectations of profits, does not amount to a breach of an obligation under this Section.")

See Joint Interpretative Instrument on the Comprehensive Economic and Trade Agreement (CETA) between Canada and the European Union and its Member States, art. 6(a) (30 October 2016), available at http://ec.europa.eu/trade/policy/in-focus/ceta/. 
The development of an identical rule on a currently-core provision across a range of major treaties involving a broad range of countries is thus a major development. Given the current centrality of FET to most investor claims in ISDS, it could over time bring greater coherence and consistency to the ISDS system (a goal that lay behind the 1967 OECD Draft Convention).

In the future, a wide range of governments and others may be providing their interpretations of the MSTFET standard. At a minimum, the expanding use of MST-FET makes it important to examine its nature, how it is determined and its content. It is also a useful benchmark - governments can decide to adjust the level of protection for covered foreign investors in a treaty, either up or down, by reference to MST-FET. They can also use it as a benchmark for domestic law rules applicable to foreign investors or all investors.

\section{Finding MST-FET norms -- the importance of studying government action and government views in identifying customary international law norms}

MST-FET clauses are by definition expressly defined by reference to customary international law. Views about the formation of customary international law vary to some degree between different constituencies. However, it is generally recognised that government action and government views about the law are the primary focus in determining customary international law. Article 38.1 of the Statute of the International Court of Justice, which is widely regarded as an authoritative statement of sources of international law, provides in part that "The Court, whose function is to decide in accordance with international law such disputes as are submitted to it, shall apply: ... b. international custom, as evidence of a general practice accepted as law".

The International Law Commission (ILC) is engaged in work on the identification of customary international law. ${ }^{53}$ Its work confirms that a strong analytical focus on government action and views is warranted in considering customary international law. Its work has proceeded on the basis that the identification of a rule of customary international law requires an assessment of both practice and the acceptance of that practice as law ("two-element" approach). ${ }^{54}$ These two requirements, "the criteria which [the International Court of Justice] has repeatedly laid down for identifying a rule of customary international law", must both be identified in any given case to support a finding that a relevant rule of customary international has emerged. ${ }^{55}$ The ILC Special Rapporteur further notes that the two elements approach is widely supported by States. International courts and tribunals likewise accept that the identification of rules of customary international law requires an inquiry into the two elements. ${ }^{56}$ The International Court of Justice (ICJ) recently stated that "it is of course axiomatic that the material of customary international law is to be looked for primarily in the actual practice and opinio juris of States."

While the primacy of the two element approach is widely accepted, there is a debate about the identification of customary international law at the ILC and elsewhere. This paper takes no position on this

53 See International Law Commission, Analytical Guide to the Work of the International Law Commission, Formation and evidence of customary international law/Identification of customary international law (with links to several reports by Michael Wood, special rapporteur from 2012 to the present, and other materials).

International Law Commission, Second report on identification of customary international law (Michael Wood, Special Rapporteur), Sixty-sixth session (Geneva, 5 May-6 June and 7 July-8 August 2014) §§ 2123 (footnotes omitted).

Id. § 22 (citation omitted).

Id. §§ 24-25; see also id., Draft Conclusions 5-7 and accompany text, pp. 15-33. 
broader debate. However, one reason to focus on governments is that under most if not all views of customary international law, government action and views are at least considered to be of central importance. As noted, section 4 and 5 below provide fact-finding about the action and views of governments in the NAFTA context.

A focus on government action and views is also valuable because they have received only limited attention in ISDS arbitral decisions and commentary. There are several monographs on FET by academics or members of law firms. FET also figures prominently in general surveys of substantive investment law. ${ }^{58}$ But the principal focus is generally on arbitral decisions and there does not appear to be any recent study of government views about the meaning of MST-FET. ${ }^{59}$ Attention to governments in this context also flows naturally from Roundtable interest and recent work on government input into treaty interpretation. ${ }^{60}$

IV. THE VALUE AND LIMITS OF GOVERNMENT VIEWS ABOUT MST-FET IN NAFTA

NAFTA appears to be the first major investment treaty expressly to limit FET to the MST under customary international law (through the treaty text and binding Joint Interpretation). As outlined above, that approach has been widely used in recent treaties between major economies. For several reasons, NAFTA government views on MST-FET standard are a valuable initial reference in an examination of the balance of investor protection and the right to regulate.

\section{A. At present, NAFTA has singularities that make it an important initial reference \\ 1. The outcomes in NAFTA FET cases differ markedly from those under FET provisions in other treaties}

NAFTA governments have had a much higher success rate in defending cases under the MST/FET provision in NAFTA than governments in FET claims under BITs. As of 2010, the 78\% NAFTA

$58 \quad$ For examples of monographs see, e.g. Alexandra Diehl, The Core Standard of International Investment Protection (2012); Dumberry 2013; Roland Kläger, 'Fair and Equitable Treatment' in International Investment Law (2013). For chapters see, e.g., Jeswald W. Salacuse, The Three Laws of International Investment: National, Contractual, and International Frameworks for Foreign Capital (2013), pp. 383-392; Rudolf Dolzer \& Christoph Schreuer, Principles of International Investment Law (2d ed. 2012), chapter VII(1).

ISDS tribunals and commentators have considered customary international law in some areas, but have tended to rely on Draft Articles developed by the ILC rather than engaging in direct reviews of state practice and government views. There are no draft articles for FET. A leading database of investment treaty cases (which digests ISDS arbitration decisions by theme) has no digest category for state practice. Investor State Law Guide, search for "state practice" in Subject Navigator (search on 5 August 2015).

David Gaukrodger, The legal framework applicable to joint interpretive agreements of investment treaties, OECD Working Papers on International Investment 2016/01; Kathryn Gordon \& Joachim Pohl (2015), "Investment Treaties over Time - Treaty Practice and Interpretation in a Changing World", OECD Working Papers on International Investment, 2015/02. 
government success rate in defending MST-FET claims was much higher than the $38 \%$ success rate of governments for FET claims under other treaties. ${ }^{61}$

The publicity given to NAFTA government success in defending FET claims under the MST-FET standard may be a factor in the recent trend to include MST-FET in major treaties around the world. In any event, by expressly tying the FET standard under NAFTA to customary international law, NAFTA governments have made the interpretation of the MST-FET provision in art. 1105 of NAFTA of potentially broader relevance for other governments that have tied their FET provisions to customary international law. Similarly, the interpretation by governments of MST-FET in other treaties may be of relevance to NAFTA, but as noted below, there is limited access to such interpretations at present.

For governments, the NAFTA experience may provide valuable information. NAFTA governments are well-known as proponents of robust investor protection in investment treaties. Officials from NAFTA governments have generally expressed satisfaction with the balance between investor protection and the right to regulate that they have achieved in their investment treaties incorporating interpretations advanced in the NAFTA context. They each have an active treaty policy and have been engaged in major negotiations.

\section{NAFTA provides unparalleled access to government interpretations of MST-FET}

NAFTA also provides unparalleled access to government views about treaties and in particular the interpretation of the MST-FET provision. NAFTA governments have been active in providing interpretations including in particular on MST-FET in general and in particular contexts. NAFTA has generated a significant body of cases since 1994 in which the same provisions are at issue and in particular the MST/FET standard in art. 1105.

The high level of transparency of ISDS under NAFTA makes many government views publicly available. NAFTA governments have interpreted the MST-FET obligation in unilateral declarations and a binding joint interpretation which are publicly available. They have also interpreted the provision in submissions in numerous NAFTA cases involving MST-FET claims; these include many non-disputing party submissions including reactions to particular case decisions. ${ }^{62}$ They have also provided publicly-available interpretations in the court cases in NAFTA countries relating to ISDS cases. Direct access to government submissions provides much more information on key interpretive issues than the necessarily brief and sometimes incomplete summaries of government views included in arbitral decisions.

Access to case materials and in particular government submissions by Roundtable participants remains the exception under other treaties. With the growth of cases against a range of governments including a broader range of Roundtable governments and the impact of the UNCITRAL Transparency Rules and

\footnotetext{
61 See UNCTAD, Fair and Equitable Treatment, UNCTAD Series on Issues in International Investment Agreements II (2012), p. 61 ("By October 2010, tribunals [had] addressed the merits of FET claims in 84 treaty-based disputes.... In NAFTA cases, only 22 per cent of those claims were accepted (4 out of 18); in BIT cases, 62 per cent were accepted (41 out of 66).").

While the degree of access to case materials and in particular government interpretations in NAFTA is high, especially in comparison to ISDS cases under most other treaties, some limits on transparency remain (beyond the protection of confidential materials). The parties' expert reports, including those of members of the arbitration bar that are largely composed of legal argument, are not always available. The investor's consent is needed for public hearings, which remain rare. Mexico appears to disclose only some of its submissions on the website of the Secretaría de Economía. More recent NAFTA government treaties generally provide for even greater transparency than NAFTA although there are exceptions.
} 
Convention, this may change. At present, however, few if any treaties provide access to government views comparable to NAFTA.

\section{Limitations of NAFTA as a source for MST/FET}

The government interpretations of customary international law relating to MST-FET under NAFTA are those of a small number of governments in a single region. The NAFTA Parties are two high-income economies and an upper middle-income economy (using the World Bank classification). ${ }^{63}$ Some governments may have differing views about the approach or content of MST-FET; some may be of the view that customary international law in NAFTA is or is part of a regional form of customary international law. Nonetheless, for the many governments using or considering the use of MST-FET in their treaties, the substantial body of views about MST-FET in the NAFTA context is a useful reference. ${ }^{64}$

\section{B. Background: Historical overview}

1. Government reaction to early expansive readings of FET in NAFTA in ISDS: the 2001 Joint Interpretation $^{65}$

Article 1105 of NAFTA is entitled Minimum Standard of Treatment. The reference to FET is found in the first subsection of article 1105 .

\section{Art. 1105 Minimum Standard of Treatment}

1. Each Party shall accord to investments of investors of another Party treatment in accordance with international law, including fair and equitable treatment and full protection and security.

A number of early cases expansively interpreted the art. 1105 reference to FET and stated that it provided protections beyond those of the international minimum standard. For example, a 2001 decision in Pope \& Talbot considered that Article 1105 required the application of "fairness elements" in addition to the minimum standard of treatment under international law. The Pope \& Talbot tribunal thus interpreted the FET provision to be "additive" to the minimum standard of treatment contained in Article 1105(1). ${ }^{66}$ In contrast to this arbitral interpretation, the Supreme Court of British Columbia, in the context of an

63 See World Bank, World Bank Country and Lending Groups, Classification.

64 Governments are of course generally free to include treaty norms that differ from customary international law either by providing greater or lesser protection to investors than customary international law, subject to mandatory jus cogens norms.

The history of these events is recounted in many books and articles, and is only briefly summarised here. See, e.g, Dumberry 2013, pp. 5 and following.

Pope \& Talbot v. Government of Canada, UNCITRAL, Award on the Merits of Phase 2, § 110 (10 April 2001) ("[I]nvestors under NAFTA are entitled to the international law minimum, plus the fairness elements."). See also Loewen, US Counter-Memorial, p. 174 (“[T]he United States disagrees with the discussion of "fair and equitable treatment" in the award by the Chapter Eleven arbitral tribunal in Metalclad Corporation v. United Mexican States, ICSID Case No. ARB(AF)/97/1 (Aug. 30, 2000). Although the award's sparse statement of reasons leaves some doubt, it appears to apply a "fair and equitable" standard without an evaluation of customary international law on the subject. To the extent that Metalclad can be read to suggest that "fair and equitable" in Article 1105(1) articulates a standard other than the international minimum standard, it is wrongly reasoned and should not be followed here."). 
application to set aside an arbitration award, found that the FET standard in art. 1105 was limited to the customary international law standard. ${ }^{67}$

In July 2001, the three NAFTA Parties, through the Free Trade Commission (FTC), expressly clarified that the FET standard in art. 1105 was limited to the customary international law standard. The Notes of Interpretation of Certain Chapter 11 Provisions ("Joint Interpretation") states as follows:

Minimum Standard of Treatment in Accordance with International Law

Article 1105(1) prescribes the customary international law minimum standard of treatment of aliens as the minimum standard of treatment to be afforded to investments of investors of another Party.

The concepts of "fair and equitable treatment" and "full protection and security" do not require treatment in addition to or beyond that which is required by the customary international law minimum standard of treatment of aliens.

A determination that there has been a breach of another provision of the NAFTA, or of a separate international agreement, does not establish that there has been a breach of Article 1105(1). ${ }^{68}$

In many subsequent unilateral statements of interpretation or non-disputing party submissions, NAFTA governments have emphasised that NAFTA tribunals are bound by the Joint Interpretation. The NAFTA governments have pointed to the express provision in NAFTA providing for binding interpretations and have emphasised that the Joint Interpretation merely reaffirmed the original intent. ${ }^{69}$ While there was some early criticism and controversy following the Joint Interpretation, tribunals in NAFTA cases have followed the Joint Interpretation and have recognised that art. 1105(1) incorporates the customary international law MST-FET standard. ${ }^{70}$

Following the 2001 Joint Interpretation expressly clarifying that art. 1105(1) of NAFTA is a MST-FET provision, NAFTA governments enjoyed considerable success in defending MST-FET claims. Claimants continued to invoke the FET provision in almost all NAFTA cases, as in ISDS generally. But until a recent

67 See Mexico v. Metalclad, (Supreme Court of British Colombia. 2001) § 62 ("What the Myers tribunal correctly pointed out is that in order to qualify as a breach of Article 1105, the treatment in question must fail to accord to international law. Two potential examples are "fair and equitable treatment" and "full protection and security", but those phrases do not stand on their own. For instance, treatment may be perceived to be unfair or inequitable but it will not constitute a breach of Article 1105 unless it is treatment which is not in accordance with international law. In using the words "international law", Article 1105 is referring to customary international law which is developed by common practices of countries.")

NAFTA Free Trade Commission, Notes of Interpretation of Certain Chapter 11 Provisions (31 July 2001).

See, e.g., Methanex, Mexico Third Non-Disputing Party Submission, pp. 7-8: ("There has been no change to the meaning of Article 1105, or amendment to the Treaty, but rather a reaffirmation and clarification of its meaning after a series of errant decisions in certain cases showed the need for the Parties to act collectively. In acting collectively, the Parties act as the guardians of the Treaty. They have reserved the legal right and the duty to clarify to tribunals the meaning of the obligations that they agreed to undertake. Once they exercise their power, a tribunal must comply with the Commission's interpretation.")

The Roundtable has recently considered joint interpretations of investment treaties more generally. See David Gaukrodger, The legal framework applicable to joint interpretive agreements of investment treaties, OECD Working Papers on International Investment 2016/01. 
and contested 2015 decision, only one case filed after the 2001 Joint Interpretation found a government liable under the MST-FET standard. ${ }^{71}$ The case involved unusual facts and the principal basis for the finding of a breach of MST-FET was the finding that the government action was intentionally designed to injure the Claimants' investment to the greatest extent possible. ${ }^{72}$

Claimants and governments continue to develop and refine their interpretations and arguments. NAFTA tribunals continued to apply a variety of approaches to defining FET. But in the absence of any findings of liability under MST-FET other than Cargill until 2015, the doctrinal variations were principally of interest to specialists. Rules from the Alleged FET List that gained wide currency as the basis for liability under other treaties based on arbitral precedent, like the doctrine of legitimate expectations, did not give rise to any damages awards under NAFTA. As Patrick Dumberry noted in his comprehensive survey of NAFTA cases on FET, no NAFTA tribunal had based a finding of liability on a violation of an investor's legitimate expectations as of $2013 .^{73}$

While NAFTA governments have been successful in defending against claims for damages under MSTFET, they have expressed sharp disagreement with some expansive interpretations by tribunals. The decision in Merrill \& Ring Forestry L.P. v. Canada set forth a broad version of MST-FET although the tribunal ultimately found no liability. ${ }^{74}$ NAFTA governments have expressly rejected the Merrill tribunal's approach. ${ }^{75}$

$71 \quad$ Cargill Inc. v. Mexico, Award (18 Sept. 2009).

72 See Cargill, § 298 (finding "most determinative the fact that the import permit was put into effect by Mexico with the express intention of damaging Claimants' ... investment to the greatest extent possible").

The Cargill case arose in the broader context of a trade dispute. The measure at issue appeared to be in the nature of trade retaliation for what Mexico considered to be a failure by the US to comply with its obligations to open its market under NAFTA. The tribunal found that the sole purpose of the import permit requirement was to change the trade policy of the United States. Cargill, § 299. Trade retaliation is permitted under certain conditions under the WTO and involves the deliberate targeting and thus the deliberate imposition of economic injury to sensitive sectors from a partner country in order to provide a strong political and economic incentive for the government to comply with its WTO obligations. These measures are designed to cause injury to traders and investors and the interaction of trade retaliation remedies and investment treaties raises complex issues. Countermeasures may also be acceptable under some conditions under general international law. The Cargill tribunal rejected Mexico's view that its measures were justifiable as countermeasures. Id. $\S \S 300,420-29$.

Dumberry 2013, p. 315.

Merrill \& Ring Forestry L.P. v. Canada, Award (31 March 2010).

See Mesa, Mexico Second Non-Disputing Party Submission $§ 10$ ("The Merrill \& Ring tribunal's obiter dicta on the interpretation and application of NAFTA Article 1105 fails to reflect a proper analysis of customary international law."); Mesa, US Second Non-Disputing Party Submission $\S 10$ and fn 23 ("The Merrill \& Ring tribunal cited no State practice or opinio juris to support its conclusion. ... The tribunal's statement, therefore, is the erroneous opinion of a single ad hoc tribunal and has no relevance for determining the content of customary international law in general or of Article 1105(1) in particular."); Eli Lilly, Canada Counter-memorial, p. 97 fn 413 ("Claimant's reliance on Merrill \& Ring Forestry LP v. Canada adds nothing to the question of what standard of treatment is owed to investors under the minimum standard of treatment under customary international law. ... The Merrill \& Ring Tribunal did not articulate a coherent view of what would be required to violate Article 1105(1) generally ...."). 
In March 2015, a majority of the tribunal in Bilcon v. Canada found Canada liable for a breach of MSTFET in connection with the process of environmental review of a mining and marine terminal project. ${ }^{76}$ This was the first NAFTA case to rely on the notion of legitimate expectations as an aspect of a breach of MST-FET. In defining the MST-FET standard, it relied on prior ISDS cases. The three NAFTA governments have all rejected the reasoning of the majority about MST-FET, as discussed further below. ${ }^{77}$ A dissent expressed strong concern about the impact of the decision on environmental protection. ${ }^{78}$

There have been several additional high-value NAFTA claims for alleged breaches of MST-FET including cases involving issues of environmental policy. ${ }^{79}$ These circumstances have generated increased governmental and societal interest in the interpretation of MST-FET under NAFTA and in its broader implications for investment treaties.

\section{NAFTA GOVERNMENT VIEWS ABOUT THE NATURE OF THE MST-FET STANDARD}

This section and the following section reflect preliminary research into government views on customary international law relating to MST-FET. Several limitations should be noted that arise from the preliminary nature of the background research for this section. First, while a substantial amount material has been reviewed, the analysis is not exhaustive. NAFTA governments have expressed views on MST-FET not reflected here.

The inquiry has also been guided to some degree by interest in explanations of the different rates of success of FET claims under NAFTA as opposed to other treaties. It thus may give prominence to

William Ralph Clayton, William Richard Clayton, Douglas Clayton, Daniel Clayton and Bilcon of Delaware, Inc. v. Canada, Award on Jurisdiction and Liability (17 March 2015) (majority opinion); id., Dissenting opinion of Professor Donald McRae. On 16 June 2015, Canada filed an application with the Federal Court of Canada seeking to set aside the award on jurisdiction and liability, on the grounds that the tribunal exceeded its jurisdiction and that the award is in conflict with the public policy of Canada.

See Mesa, US Second Non-Disputing Party Submission $§ \S ~ 8-22$ ("the Bilcon tribunal failed to apply customary international law when interpreting and applying Article 1105(1). Specifically, as addressed below, the Bilcon tribunal failed to recognize that the burden is on a claimant to establish the existence and applicability of a rule of customary international law, and failed to determine whether the Bilcon Claimants had met that burden. In addition, the Bilcon tribunal incorrectly adopted standards from prior NAFTA Chapter Eleven awards, which are not founded in State practice and opinio juris."); Mesa, Mexico Second Non-Disputing Party Submission, §§ 9-11; Canada Response to Non-Disputing Party Submissions, § 18 ("All three NAFTA Parties agree on the interpretation of Article[].. $1105 \ldots$ and the fundamental errors made by the Bilcon tribunal.").

Bilcon v. Canada, Dissenting opinion of Professor Donald McRae (17 March 2015) §§ 44-51.

See Lone Pine Resources, Inc. v. Canada, ICSID Case UNCT 15/02 (claim for \$ 110 million; moratorium on the practice of hydraulic fracturing, or fracking, for natural gas); Mesa Power Group LLC $v$. Government of Canada, PCA Case No. 2012-17 (claim for \$746 million; incentives to promote green energy); Windstream Energy LLC v. Government of Canada, UNCITRAL (claim for $\$ 457$ million; same). Arbitral decisions in these cases are not addressed herein. 
interpretations by NAFTA governments that are narrower than those of ISDS tribunals or commentators because these may be of importance in explaining the different outcomes. All of the NAFTA governments support robust foreign investor protection. However, as set forth below, they generally consider that this is consistent with a clearly-defined scope of liability under MST-FET.

Third, the analysis sets forth the views of individual governments which may differ. There is a significant degree of convergence on the approach. However, the analysis is not limited to issues on which all NAFTA governments agree. In some cases, only some governments have expressed a view. In other cases, there are differences in approach. While efforts have been made to reflect these differences, not all views may be reflected on a particular issue.

Fourth, the inclusion of government interpretations here should not be seen as definitive statements of their position. Views on customary international law can evolve and may have evolved from the positions recorded herein. Characterisations of views here for purposes of discussion may not capture the full complexity or nuances of views. Recourse should be made to the original documents. Interpretations expressed in particular cases either as a defending or non-disputing party may be linked to the particular facts or context of the case.

Fifth, what is addressed here are views about rules of MST-FET that can form the basis for damages claims by foreign investors. The NAFTA government are generally strong supporters of many if not all of the principles discussed below as a matter of investment policy. They have supported the inclusion of many of them in policy documents such as the OECD's Policy Framework for Investment. The narrow issue addressed here is their role, if any, as a basis for government damages liability in ISDS.

The analysis here is expressly devoted to presenting government views: titles and sub-titles refer to interpretations by at least one government. The views of the government are provided for information. No view is expressed about the whether any particular government view of FET/MST or customary international law is correct. The text includes interpretations without regard to whether they have been accepted by tribunals. As noted, a concluding section includes a few comparative observations including about tribunal decisions, but the main focus is on government views.

\section{A. The nature of the MST-FET inquiry and the limited role of the ISDS tribunal in resolving MST-FET claims}

1. The MST-FET standard under customary international law is determined by reference to a general and consistent practice of States that they follow from a sense of legal obligation

All of the NAFTA governments have interpreted the reference to customary international law to refer to law established by reference to a general and consistent practice of States that they follow from a sense of legal obligation.

a. State practice - a general and consistent practice of States

The US has quoted the International Court of Justice with regard to the principle that in order to establish a customary international law rule, State practice, including that of States whose interests are specially affected, should have been both extensive and virtually uniform in the sense of the provision invoked:

Establishing the existence of a rule of customary international law, however, is no small task. The International Court of Justice ("ICJ") has stated that to establish a rule of customary international law, it is "an indispensable requirement" to demonstrate that State practice, including 
that of States whose interests are specially affected, should have been both extensive and virtually uniform in the sense of the provision invoked; and should moreover have occurred in such a way as to show a general recognition that a rule of law or legal obligation is involved."

Mexico has similarly stated that only settled and well-accepted legal principles fall within the category of customary international law:

Although customary international law can mature quickly on occasion (for example, rules relating to fishing zones), generally States are not quick to acknowledge the existence of a new customary rule of international law.

Accordingly, only settled and well-accepted legal principles fall within this category of international law. By way of example, the International Court of Justice's most recent pronouncement on the local remedies rule in the context of a bilateral investment treaty, rendered in 1989, the Elettronica Sicula S.p.A. Case (the "ELSI Case"), identified and applied longstanding principles of customary international law. The strict tests for the local remedies rule and denials of justice formulated in the early part of the last century and applied since then are settled and well-accepted, and therefore are properly characterized as rules of customary international law. ${ }^{81}$

Government submissions have also reviewed state practice to refute assertions about alleged rules of customary international law. ${ }^{82}$

\section{b. Opinio juris}

The NAFTA governments have repeatedly stated that opinio juris is an essential component of customary international law. As noted above, the US has pointed out that evidence of extensive and virtually uniform state practice should also show that it "has occurred in such a way to show a general recognition that the legal obligation is involved". ${ }^{83}$ Mexico has stated that surveys of many States and different legal systems are required to demonstrate whether States by their conduct evidence a willingness to be bound by the rule of law that is being propounded. Substantial uniformity across many States and many different legal systems is required in order to provide a basis for a customary international law rule:

To determine the content of customary international law, the International Court of Justice looks to the opinio juris of States: that is, whether States by their conduct evidence a willingness to be bound by the rule of law that

Glamis, US Rejoinder, p. 141 (quoting North Sea Continental Shelf (Federal Rep. of Germany v. Netherlands/Denmark), 1969 I.C.J. § 74 (Judgment of Feb. 20)); [Mesa, Bilcon, US Non-Disputing Party Submission $§ 13$ (same).]

For convenience, government views in submissions filed in NAFTA cases are cited herein with short references to the case name, the government making the submission and the nature or short title of the document. Annex 2 provides full information about cited government documents.

Loewen, Mexico Second Non-Disputing Party Submission, pp. 2-3 (citation omitted).

See, e.g., Apotex Holdings, US Rejoinder on Merits, §§ 300-301.

Glamis, US Rejoinder, p. 141 (quoting North Sea Continental Shelf (Federal Rep. of Germany v. Netherlands/Denmark), 1969 I.C.J. §74 (Judgment of Feb. 20)); Mesa, US Second Non-Disputing Party Submission $\S 13$ (same) 
is being propounded. This requires the survey of many States and many different legal systems. While complete uniformity is not required, substantial uniformity is. ${ }^{84}$

All NAFTA governments have rejected assertions that the signing of BITs with FET clauses creates customary international law. First, they have stated that there is no opinio juris because there is no obligation to sign BITs with FET clauses. NAFTA governments have stated that in order to demonstrate customary international law, it would need to be shown that the treaties were signed out of a sense of obligation (opinio juris). They consider that there is no evidence that this is the case. ${ }^{85}$ All three NAFTA States have expressly rejected as erroneous the view of the Pope \& Talbot tribunal that the content of contemporary customary international law reflects the concordant provisions of many BITs. ${ }^{86}$

Second, Canada and the US have also rejected BITs as a source of customary international law on MSTFET because FET provisions in treaties vary widely. Thus, state practice lacks the necessary element of consistency. ${ }^{87}$

3. Domestic law, domestic court decisions and official declarations by relevant state actors are relevant state practice for determining whether a particular rule exists as part of MST-FET

The US has emphasised that domestic law, domestic court decisions and official statements by relevant government actors are important evidence of state practice:

The International Court of Justice has cited the types of evidence that can be used to demonstrate that a rule of customary international law exists. In its recent judgment in Jurisdictional Immunities of the State, for example, the Court identified as examples of State practice relevant national court decisions and domestic legislation dealing with the particular issue alleged to be the norm of customary international law, as well as official declarations by relevant State actors on the subject. The Court emphasized that " $[\mathrm{i}] \mathrm{t}$ is of course axiomatic that the material of customary

84 Loewen, Mexico Second Non-Disputing Party Submission, pp. 2-3 (footnote omitted). rejected the notion that BITs create customary international law") (bold in original) (citing various government documents).

See Mondev Int'l Ltd. v. United States, Award (11 Oct. 2002) § 11 (noting that the submissions of all three NAFTA Parties rejected the view of the tribunal in Pope \& Talbot); ADF, Mexico Second Non-Disputing Party Submission, p. 19-20 ("It is impossible to infer from the existence of a large number of BITs alone that any particular provision therein represents a rule of customary international law merely by reason of its commonality. The [Pope] Tribunal did not refer to the essential additional requirement of opinio juris. ... $[\mathrm{N}]$ otwithstanding that there has been a proliferation of bilateral investment treaties, it has not been established that any even purport to modify the standards of customary international law in relation to this aspect of the treatment of aliens.") (citation omitted).

See Chemtura, Canada Rejoinder, $§ 176$ (BITs are not relevant to MST-FET because, inter alia, "state practice with regard to fair and equitable treatment is far from uniform"; "One of the two elements required to establish custom is consistent State practice. The signature of BITs fails to prove this element of the test. Contrary to the Claimant's suggestion, State practice with regard to "fair and equitable" treaty provisions is far from uniform"; noting UNCTAD's identification of seven different basic models of FET provisions); Glamis, US Rejoinder, p. 142. 
international law is to be looked for primarily in the actual practice and opinio juris of States."). ${ }^{88}$

The US has also used comparative domestic law analysis to demonstrate that a claimant has failed to satisfy its burden of proof about a rule of customary international law. ${ }^{89}$ For example, the US has cited its domestic law as state practice to refute a claim about the existence of an alleged customary international law rule that is more investor-protective. ${ }^{90}$

\section{Government submissions in disputes are an important source of state practice}

NAFTA governments frequently cite the interpretations of MST-FET by other NAFTA governments. Reliance has been placed both on interpretations by respondent and non-disputing governments. ${ }^{91}$ The NAFTA governments have pointed to agreed interpretations with regard to customary international law in their submissions. ${ }^{92}$

Some experts retained by investors have suggested that governments' interpretations setting out limits to investor protections in defensive briefs filed in objecting to liability in a particular case should be discounted. The US has rejected this view:

With respect to U.S. State practice, [investor-retained expert] Professor Wälde argues that U.S. practice is best indicated by its offensive briefs, such as those filed in the ELSI case, as opposed to the United States' "defensive advocacy" before NAFTA tribunals. See Wälde Rep. at IV-4 \& IV-16. This argument is baseless. The United States' submissions before NAFTA tribunals are indeed part of U.S. State practice. The annual publication Digest of United States Practice in International Law provides

See Mesa, US Non-Disputing Party Submission, § 11 citing Jurisdictional Immunities of the State (Germany v. Italy: Greece intervening), 2012 I.C.J. 99, 122-23 (Judgment of 3 Feb. 2012).

Apotex Holdings, US Rejoinder, §§ 299-301 (reviewing US, Canadian and civil law countries with regard to claimant's proposed rule of due process; “Apotex has failed to identify a single State anywhere in the world that recognizes Apotex's proposed rule of customary international law. Indeed, all evidence is to the contrary.')

See Glamis, US Rejoinder, p. 184-85 ("U.S. domestic law - which is evidence of State practice - does not provide a cause of action for frustration of expectations in the absence of a contractual or quasi-contractual relationship between the parties. Given this evidence, it would be extraordinary for this Tribunal to conclude that although customary international law does not even protect expectations that are backed up by contractual commitments, it does so where there are lesser - or indeed no - forms of assurances made."); id., p. 183-84 (underlining that under US domestic law, "[w]here an agency of the federal government acts in a sovereign capacity for the benefit of the public, the United States is not subject to an estoppel which would impede the exercise of its governmental functions.") (citation omitted).

91 See, e.g., Grand River, US Rejoinder, p. 72 n.214 (referring to and citing views of each of the three NAFTA governments on the content of MST under customary international law ); Mesa, Canada Response to Non-Disputing Party Submissions, $§ 7$.

See, e.g., Mesa, Canada Response to Non-Disputing Party Submissions, § 7 ("Canada, the United States and Mexico agree on the proper interpretation of NAFTA Article 1105. All three NAFTA Parties agree that the NAFTA Free Trade Commission's 2001 Notes of Interpretation of Certain Chapter 11 Provisions (the "FTC Note") is binding on this Tribunal and reflects the high threshold for a breach of the Minimum Standard of Treatment.") (citations omitted). See David Gaukrodger, The legal framework applicable to joint interpretive agreements of investment treaties, OECD Working Papers on International Investment 2016/01. 
the public with a ready source of the United States' views and practice in the arena of public and private international law. See Office of the Legal Adviser, Digest of International Law, at http://www.state.gov/s/1/c8183.htm. This publication routinely includes submissions made by the United States to NAFTA Chapter Eleven tribunals. See, e.g., Office of the Legal Adviser, 2004 Digest of United States Practice in International Law 572, 572-601 (Sally J. Cummins ed.) (including excerpts of submission from "[s]elected cases reflecting U.S. practice"). Professor Wälde cites no support whatsoever for his novel view of what constitutes State practice. The idea that State practice only "counts" when the State is acting in a manner that serves the interests of a proponent of that action is absurd. See Wälde Rep. at IV-16 (suggesting that U.S. practice is "best" and more "objective[ly]" indicated by offensive advocacy as opposed to "U.S. state practice [ ] influenced by considerations of defensive advocacy"). If such were the case, a State could simply disavow a portion of its State practice when doing so was expedient. ${ }^{93}$

a. Arbitral interpretations of autonomous FET provisions have no relevance for the interpretation of MST-FET

Investors in NAFTA cases frequently cite ISDS cases from outside NAFTA that have adopted broad readings of the FET provision in the relevant treaty. Many of these decisions relate to treaties with FET clauses that are not expressly limited to the MST. As noted above, ISDS tribunals increasingly interpret such clauses as autonomous clauses.

The US and Mexico have stated that awards that interpret FET provisions that are not limited to the MST are irrelevant to the interpretation of MST-FET:

Although States may decide, expressly by treaty, to extend protections under the rubric of "fair and equitable treatment" and "full protection and security" beyond that required by customary international law, that practice is not relevant to ascertaining the content of the customary international law minimum standard of treatment. Arbitral decisions interpreting "autonomous" fair and equitable treatment and full protection and security provisions in other treaties, outside the context of customary international law, do not constitute evidence of the content of the customary international law standard required by Article $1105 .^{94}$

For the NAFTA governments, the inquiry about a provision tied to customary international law is fundamentally different than the interpretation of treaty standards and tribunals have a different role.

93 Glamis, US Rejoinder, p. 152 n. 608.

$94 \quad$ Mesa, US Non-Disputing Party Submission, § 6 (footnote omitted); Cargill, Mexico Duplica § 127 (“El estándar de trato justo y equitativo que la demandante sugiere es el aplicable en otros tratados y no en el TLCAN. »). 
b. The autonomous standards have not merged with MST-FET

NAFTA governments have rejected the claim, advanced by claimants and some commentators, that the standards for autonomous FET have merged with the MST-FET standard:

Even though almost every case [the claimant] cites in support of its Article 1105 claim interprets the fair and equitable treatment provision involved as an "autonomous" standard without reference to the customary international law minimum standard of treatment, [the claimant] repeatedly relies on those decisions as evidence of the content of the customary international law minimum standard of treatment. But [the claimant] has produced no evidence or support for its proposition that the interpretations offered by those tribunals reflect customary international law. These decisions, therefore, are of scant assistance to the Tribunal. ${ }^{95}$

c. Arbitral interpretations of MST-FET play a role only insofar as they have addressed state practice and opinio juris, the elements of customary international law.

The NAFTA governments have repeatedly insisted that the decisions of arbitral tribunals are not themselves a source of customary international law. ${ }^{96}$ Consequently, ISDS awards that merely set forth arbitral views about customary international law are not relevant:

As Canada has noted in its Counter-Memorial, citing Sir Hersch Lauterpacht, "[d]ecisions of international courts are not a source of international law... [t]hey are not direct evidence of the practice of States or of what States conceive to be the law". Arbitral decisions are relevant to the determination of custom only to the extent that they contain valuable analysis of State practice. They may provide a useful tool for determining the content of customary international law in this way. They do not in themselves constitutes the practice of States. The cases cited by Claimant, as noted above, do not contain an analysis of either State practice or opinio juris. ${ }^{97}$

Awards that rely on earlier ISDS awards that set forth arbitral views have no greater relevance. For example, in its recent non-disputing party brief in Mesa addressing the Bilcon decision, the US rejected an arbitral formulation of the minimum standard because it is not based on analysis of an examination of State practice and opinio juris:

formulation of the minimum standard of treatment [in Waste Management $I I]$, by its terms, is based entirely on other arbitral awards, rather than on

95 Glamis, US Rejoinder, p. 150 (footnote omitted); Windstream, Canada Counter-Memorial, p. 146 ("The Claimant Has Failed to Prove that the Autonomous Fair and Equitable Treatment Standard and the Customary International Law Minimum Standard of Treatment of Aliens Are the Same Standard").

See Mesa, Mexico Second Non-Disputing Party Submission, § 10 ("Mexico concurs with Canada's submission that decisions of arbitral tribunals are not themselves a source of customary international law ...."); Mesa, Canada Response to Non-Disputing Party Submissions, § 11 ("Canada has explained at length in its pleadings as to why decisions of international investments tribunals are not a source of State practice for the purpose of establishing a new customary norm."). 
an examination of State practice and opinio juris. Accordingly, the Bilcon tribunal erred in relying on it. ${ }^{98}$

Only tribunal decisions that analyse customary international law by reference to state practice and opinio juris are can be relevant to the inquiry about a rule of customary international law. ${ }^{99}$

\section{B. The claimant's burden of proof with regard to the law and the role of the tribunal}

All of the NAFTA Parties have stated that the claimant bears the burden of establishing that the norm it invokes exists as a matter of customary international law. The US recently criticised a tribunal decision for failing to apply this requirement. ${ }^{100}$ This requires that the claimant establish both state practice and opinio juris with regard to the norm at issue. ${ }^{101}$

NAFTA governments have also insisted on the claimant's burden with regard to each of the various rules that it alleges from the Alleged FET List:

The Claimant asserts that the minimum standard of treatment afforded to foreign investors by customary international law contains "four pillars," which it defines as protection against treatment that is "discriminatory," "arbitrary," "grossly unfair, unjust or idiosyncratic," and "nontransparent." The Claimant, however, submits no evidence of state practice or opinio juris to support its assertion, but instead merely cites various investment treaty arbitral awards in support of its position.

This reliance on awards, however, falls far short of what is required to fulfil the Claimant's burden of proving a rule of custom. Arbitral awards

Mesa, US Second Non-Disputing Party Submission, $§ 16$; see also Mesa, Mexico Second Non-Disputing Party Submission $\S 10$ ("Mexico concurs with Canada's submission that decisions of arbitral tribunals are not themselves a source of customary international law and that the Bilcon tribunal's reliance on Merrill \& Ring was misplaced. The Merrill \& Ring tribunal's obiter dicta on the interpretation and application of NAFTA Article 1105 fails to reflect a proper analysis of customary international law.")]; Apotex Holdings, US Rejoinder, p. 156 n.698 (rejecting reliance on an arbitral interpretation not based on State practice and opinio juris).

99 Commentators have noted that ISDS awards, even under NAFTA or other treaties that apply the MSTFET, have rarely if ever addressed the elements of customary international law relating to FET.

See Mesa, US Second Non-Disputing Party Submission, § 8: ("Specifically, as addressed below, the Bilcon tribunal failed to recognize that the burden is on a claimant to establish the existence and applicability of a rule of customary international law, and failed to determine whether the Bilcon Claimants had met that burden.").

101 See UPS, Mexico Fourth Non-Disputing Party Submission, § 13 ("The Tribunal, citing jurisprudence of the International Court of Justice, correctly recognized that to establish a rule of customary international law two requirements must be met: consistent State practice and an understanding that that practice is required by law, i.e., opinio juris. The burden of proving the existence of a customary international law rule and its breach rests upon the complainant.") (footnote omitted); Mesa, Mexico Second Non-Disputing Party Submission, § 9 ("The NAFTA Parties have repeatedly and consistently submitted that Article 1105 reflects a standard that develops from State practice and opinio juris. As the United States stated in its first Article 1128 submission in this proceeding, "the burden is on a claimant to establish a relevant obligation under customary international law that meets the requirements of State practice and opinio juris".); Mercer, Canada Counter-Memorial, $\S \S 461-465$ (footnotes omitted) ("In order to prove the existence of a rule of customary international law, two requirements must be met: consistent state practice and an understanding that such practice is required by law (opinio juris). ... The burden of proving the existence of a rule of customary international law rests on the party that alleges it. ..."). 
cannot create customary international law - only states can create custom. ${ }^{102}$

Specificity requirements for proof of law can address a tendency to take a broad principle and use it as the basis for a wide range of challenges to government policy. The US has stated that the claimant's evidence must establish the existence of the claimed rule with particularity. It would not be sufficient for claimants to establish the existence of general and abstract customary international law rules requiring procedural protections in administrative actions. Rather, the claimant needed to establish the existence of specific procedural protections provided in the context of administrative decision-making relating to health and safety regulation of pharmaceutical imports. ${ }^{103}$

\section{NAFTA GOVERNMENT INTERPRETATIONS OF THE CONTENT OF MST-FET}

\section{A. Overall views \\ 1. The MST is an umbrella concept for a set of discrete rules}

Mexico and the US have stated that the MST is an umbrella concept. Its content includes a set of rules. For example, in Bilcon, the US stated that "[a]s the United States has observed in previous submissions in NAFTA Chapter Eleven cases, the minimum standard of treatment is an umbrella concept reflecting a set of rules that, over time, has crystallized into customary international law in specific contexts". ${ }^{104}$ Mexico has affirmed that "[c]ustomary international law has developed specific rules to deal with the treatment accorded to aliens. These rules, which are rather basic, perhaps even rudimentary, deal with, for example, the right to unhindered access to the courts and to a fair trial, are discussed in consistent terms by qualified publicists and by international arbitral tribunals."

The MST includes rules on fair and equitable treatment and full protection and security. ${ }^{106}$ The views of Mexico and the US have been set forth as follows:

"[F]air and equitable treatment" and "full protection and security" are provided as examples of the customary international law standards incorporated in Article 1105(1). The plain language and structure of

\footnotetext{
102 Mercer, Canada Counter-Memorial, $\S \S 461-465$ (footnotes omitted).

$103 \quad$ Apotex Holdings, US Rejoinder on Merits, § 290.

104 Bilcon, US Non-Disputing Party Submission, $§ 4$.

$105 \quad U P S$, Mexico Fourth Non-Disputing Party Submission, § 14
}

106 Full protection and security ("FPS") has rarely been at issue in NAFTA. In some ISDS cases outside NAFTA, investors and tribunals have interpreted FPS broadly to apply to regulatory changes. See, e.g. National Grid v. Argentina, Award, § 189. These interpretations have not been prominent in NAFTA cases. The core debate in NAFTA has been over the content of the MST that related to FET.

The US has stated that customary international law rules also includes rules on expropriation. The customary international law rules on expropriation are rarely at issue because NAFTA and most other treaties set out explicit rules on expropriation. There is little role if any for customary international law. 
Article 1105(1) requires those concepts to be applied as and to the extent that they are recognized in customary international law. They are not to be applied in a subjective and undefined sense without reference to international law standards.

The international law minimum standard is an umbrella concept incorporating a set of rules that have crystallized over the centuries into customary international law in specific contexts. The relevant principles are part of the customary international law of state responsibility for injuries to aliens. ${ }^{107}$

Consistent with the view that the MST is comprised of a set of discrete rules, the three NAFTA governments have sharply criticised the suggestion of the tribunal in Merrill that the MST-FET clause gives rise to a general arbitral inquiry about "fairness, equity and reasonableness". ${ }^{108}$ The NAFTA governments have pointed to the lack of analysis of the elements of customary international law or cited critical commentary about the Merrill tribunal's reasoning. ${ }^{109}$

\section{Few norms have been established as part of the MST under customary international law}

The United States has regularly stated that customary international law has crystallised to establish a MST "in only a few areas":

Currently, customary international law has crystallized to establish a minimum standard of treatment in only a few areas. One such area, which is expressly addressed in Article 1105(1), concerns the obligation to provide "fair and equitable treatment." This includes, for example, the obligation not to deny justice in criminal, civil or administrative adjudicatory proceedings, such as when a State's judiciary administers justice to aliens in a "notoriously unjust" or "egregious" manner "which offends a sense of judicial propriety." 110

$107 \quad A D F$, Mexico Second Non-Disputing Party Submission, p. 8 (quoting Pope \& Talbot, US Second NonDisputing Party Submission, § 8).

$108 \quad$ Merrill, Final Award, $§ 210$.

109 See Mesa, US Second Non-Disputing Party Submission, p. 6 n.23 ("The Merrill \& Ring tribunal cited no State practice or opinio juris to support its conclusion. See Patrick Dumberry, The Fair and Equitable Treatment Standard: A Guide to NAFTA Case Law On Article 1105 at 115 (2013) (observing that the tribunal failed "to cite a single example of State practice in support of" its "controversial findings") (emphasis in original); UNCTAD, Fair and Equitable Treatment - UNCTAD Series on Issues in International Agreements II at 57 (2012) ("The Merrill \& Ring tribunal failed to give cogent reasons for its conclusion that MST made such a leap in its evolution, and by doing so has deprived the 2001 NAFTA Interpretive Statement of any practical effect."). The tribunal's statement, therefore, is the erroneous opinion of a single ad hoc tribunal and has no relevance for determining the content of customary international law in general or of Article 1105(1) in particular."); Mesa, Canada Observations on Award, § 17 ("the decision of the tribunal in Merrill and Ring v. Canada, do[es] not conduct the required analysis of customary international law"); Mesa, Mexico Non-Disputing party submission, p. 6 ("The Merrill \& Ring tribunal's obiter dicta on the interpretation and application of NAFTA Article 1105 fails to reflect a proper analysis of customary international law.")].

110 See, e.g., Mesa, US Second Non-Disputing Party Submission, p. 6-7 (citations omitted); see also UPS, Mexico Fourth Non-Disputing Party Submission, $§ \S 14-15$ (The specific rules developed under customary international law " are rather basic, perhaps even rudimentary .... Since the rules are so basic and modern State action in the ordinary course of events rarely offends the rules ...."). 
The NAFTA governments have recognised that the customary international law can evolve. ${ }^{111}$ Proof of the development of a new customary international law norm requires proof of state practice and opinio juris. ${ }^{12}$ Customary international law also does not evolve just because time passes. ${ }^{113}$ The US has also stated that contrary state practice can also destroy a customary international law rule. ${ }^{114}$ The history of controversy over customary international law on economic and social policy makes it improbable that a widespread range of States have agreed to new expansive customary international law rules in a short period. ${ }^{115}$

The MST is an absolute and minimum standard that establishes a floor

NAFTA governments have stated that MST-FET sets an absolute, not a relative standard, and that it is a minimum standard. For example, the US has stated that " $[t]$ he three 'treaty drafters' definitively agree that Article 1105 is an absolute - not a relative - standard". ${ }^{116}$ Mexico has distinguished between Article 1102's "relative standard of national treatment" and Article 1105's "absolute standard, the minimum standard of treatment required by international law". 117

All three NAFTA governments agree that the threshold for demonstrating a violation of the MST-FET standard in art. 1105 is high. ${ }^{118}$ For example, "Mexico has stated that it concurs with Canada's view that "[t)he conduct of government toward the investment must amount to gross misconduct, manifest injustice

111 See Grand River, US Rejoinder, p. 72 n.214 ["Indeed, all three NAFTA Parties have confirmed that the content of the customary international law minimum standard of treatment is not static or limited to conduct that was prohibited in the early part of the 20th Century.") Citations to government interpretations omitted).

See Glamis, US Rejoinder, pp. 152-53 (“Customary international law, however, does not evolve every time a new decision is issued by an arbitral tribunal; its evolution - if any - depends on evidence of a general practice or custom among States.”) (footnotes omitted).

$A D F$, Mexico Second Non-Disputing Party Submission, p. 21 ("The simple fact that the Neer decision was rendered in 1926 cannot support the conclusion urged by the Claimant that the Neer standard no longer represents a leading case on the customary international law standard.")

See Glamis, US Rejoinder p. 153 n.610 (“customary international law may even devolve.") (citations omitted).

115 Glamis, US Rejoinder, p. 153.

116 See Glamis, US Rejoinder, n.580 (citing Department of External Affairs, North American Free Trade Agreement: Canadian Statement on Implementation, in Canada Gazette (Jan. 1, 1994) ("SOI"), at 149 (where Canada contrasts national treatment, which "provides a relative standard of treatment," with Article 1105, which "provides for a minimum absolute standard of treatment, based on long-standing principles of customary international law"); Methanex, Mexico Fourth Non-Disputing Party Submission § 14 (distinguishing between Article 1102's "relative standard of national treatment" and Article 1105's "absolute standard, the minimum standard of treatment required by international law").)

118 See, e.g., Mesa, Canada Response to Non-Disputing Party Submissions, § 9 ("both the United States and Mexico agree with Canada that the threshold for demonstrating a violation of Article 1105 is high") (citing Second Submission of the United States of America, § 20: “Accordingly, "there is a high threshold for Article 1105 to apply"”) and Second Submission of Mexico Pursuant to NAFTA Article 1128, § 8: ("the threshold for establishing a breach of the minimum standard of treatment at customary international law is high"). 
or, in the classic words of the Neer claim, an outrage, bad faith or the willful neglect of duty". ${ }^{119}$ Canada has similarly emphasised that a "high threshold exists for the breach of customary MST". ${ }^{20}$

The US has stated that as a legal matter, even if a claimant were able to demonstrate that the measures at issue were "[un]necessary, [un]suitable," or "[dis]proportionate," that would not support a finding of a violation of the international minimum standard. That is because under international law, every State is free to "change its regulatory policy." And every State "has a wide discretion with respect to how it carries out such policies by regulation and administrative conduct." States are thus necessarily accorded "wide regulatory "space"" for carrying out their objectives. ${ }^{121}$

6.

Deference - standard of review

The NAFTA governments have also stated that tribunals should accord a high degree of deference to governments in reviewing alleged breaches of MST-FET. For example, the US has stated that (i) determining a breach of the minimum standard of treatment "must be made in the light of the high measure of deference that international law generally extends to the right of domestic authorities to regulate matters within their borders"122; (ii) "international law grants States broad discretion in making legislative decisions, and ... tribunals will not second-guess a State's determination to enact economic legislation or regulations to address a matter of public concern" ${ }^{123}$; and (iii) "tribunals applying international law accord a high degree of deference to States in their administrative processes ....". ${ }^{24}$

\section{Violation of domestic administrative law is insufficient to show breach of MST-FET}

NAFTA governments have also emphasised that their domestic courts apply more demanding standards to government action than the MST. As stated by Mexico, MST-FET "expresses a minimum. standard of conduct under international law to which a NAFTA Party must adhere in its treatment of investors of another Party to the NAFTA. It does not vest a Chapter Eleven tribunal with the jurisdiction to judicially review the Party's conduct in the same fashion as a domestic court of that Party could conduct such a review." ${ }^{25}$ The MST involves basic standards that are rarely at issue. ${ }^{126}$ Domestic courts engaged in judicial review, which generally cannot award damages, can sanction behaviour that does not meet the much more demanding international standard for liability. ${ }^{127}$

\footnotetext{
119 Pope \& Talbot, Mexico Third Non-Disputing Party Submission, p. 4.

120 Chemtura, Canada Rejoinder, p. 50 (bold in original).

$121 \quad$ See Glamis, US Rejoinder, p. 188.

122 Mesa, US Non-Disputing Party Submission, § 9 (citation omitted).

123 Glamis, US Rejoinder, p. 187.

$124 \quad$ Id. pp. 187-88. See Mercer, Canada Rejoinder Memorial (31 March 2015) $\$ 364$ (referring to "the high level of deference to be afforded to domestic authorities" in considering a claim under MST-FET).

125 Pope \& Talbot, Mexico Third Non-Disputing Party Submission, p. 2 (contrasting other provisions of NAFTA allowing for review under domestic law ). customary international law "are rather basic, perhaps even rudimentary .... [M] odern State action in the ordinary course of events rarely offends the rules ..." ). 
The US has stated that it is not the role of an international tribunal applying international law to either decide whether administrative agencies acted in compliance with all domestic procedures or whether the procedures employed conformed to some international standard:

Glamis's claim boils down to a complaint that the [Bureau of Land Management] and the [Department of the Interior] made determinations that Glamis contends were either wrong, in its view, or contrary to U.S. law. Glamis's contention that these determinations were therefore arbitrary is both meritless and woefully insufficient to support a finding of a violation of the customary international law minimum standard of treatment.

The manner in which governments administer their laws differs among States, and it is not the role of an international tribunal applying international law to either decide whether administrative agencies acted in compliance with all domestic procedures or whether the procedures employed conformed to some international standard. ${ }^{128}$

8. The US policy of not granting greater substantive protections to treaty-covered foreign investors than to US investors under US law is a relevant consideration

The US has been subject to a 2002 Congressional instruction that its treaties provide no greater substantive rights to covered foreign investors than US investors have under domestic law. It has pointed to this fact as relevant to the interpretation of the MST in NAFTA art. 1105(1) because it encompasses the same minimum standard of treatment obligation found in trade agreements negotiated subject to the 2002 instruction. In its view, this suggests that MST-FET should not provide greater protection to foreign investors than US domestic law:

As the United States explained in its Counter-Memorial, in the Trade Promotion Authority Act of 2002, Congress explicitly instructed the United States Trade Representative to negotiate free trade agreements that "[do] not accord [...] greater substantive rights [to foreign investors] with respect to investment protections than United States investors in the United States [are accorded under U.S. law]." Bipartisan Trade Promotion Authority Act of 2002 ("TPA"), 19 U.S.C. § 3802(b)(3); see CounterMem. at 233-34. This suggests that neither did Congress intend for Article 1105(1), which encompasses the same minimum standard of treatment obligation found in trade agreements negotiated subject to the TPA, to extend greater protections to Canadian and Mexican investors than those available to U.S. investors under U.S. domestic law. As such, the Tribunal can infer that Congress would not construe Article 1105 as conferring responsibility upon the United States for the frustration of a foreign investors' expectations, when no such liability exists under U.S. domestic law. ${ }^{129}$

\footnotetext{
128 Glamis, US Rejoinder, p. 206.

$129 \quad$ Glamis, US Rejoinder, n.710.
} 


\section{B. NAFTA government views on specific norms proposed by claimants, commentators or ISDS cases as part of Alleged FET Lists}

1. Although NAFTA claimants have rarely provided evidence of the two elements of customary international law in their submissions, NAFTA governments have generally decided not to rest their defence in ISDS cases solely on that basis

As set forth above, NAFTA governments consider that claimants asserting that a rule exists under MSTFET have the burden of proof. Claimants must demonstrate the existence of both widespread and consistent state practice and opinio juris. Arbitral views that do not address those elements - the vast majority -- are not relevant.

There appear to have been few if any attempts by investor claimants in NAFTA to show the existence of customary international law rules under MST-FET using broad surveys of state practice and opinio juris. As noted by the tribunal in Cargill, such surveys are difficult to carry out. It may be challenging to collect evidence for the existence of a number of the rules in the Alleged FET Lists as part of customary international law.

Given the lack of investor evidence in most if not all cases, governments could simply rely on their interpretation about the claimants' burden of proof and the sources of customary international law. Provided their interpretation is applied by the tribunal, if would suffice for the governments to point out that the investor has not supplied evidence of customary international law using the traditional sources. The claim could then be dismissed.

In practice, it appears that no government has simply relied on this interpretation and requested dismissal of MST-FET claims. Rather, after setting out their views, they go on to address ISDS cases that do not address customary international law elements, frequently as a subsidiary argument. Governments may be concerned that arbitrators are likely to refer to arbitral precedents.

For example, the US has consistently excluded the relevance of ISDS precedents that do not address the elements of customary international law. Since very few awards canvas evidence of these elements of customary international law, most awards are not relevant under this reasoning. However, after noting on this basis that the claimant's reliance on irrelevant awards is unavailing, the US nonetheless addresses the awards. The US thus typically argues in the alternative that even if ISDS cases were relevant, the claimant would lose under the standards enunciated in those cases. The US generally refers to ISDS cases and uses them in argument in response to claimant's reliance on them, but without recognising their relevance.

Canada and Mexico appear to be have adopted a less trenchant approach to ISDS cases in parts of their arguments. They appear to have at times accepted some views about MST-FET from ISDS cases that do not address state practice or opinio juris. Generally, the issue of proof of customary international law based on the traditional elements has not been addressed in this context.

2. NAFTA governments have recognised the obligation not to deny justice in adjudicatory proceedings as a rule established under MST-FET

All of the NAFTA government have recognised that the obligation not to deny justice in adjudicatory proceedings is a rule established under MST-FET:

[O]nly settled and well-accepted legal principles fall within [customary international law]. ... The strict tests for ... denials of justice formulated in the early part of the last century and applied since then are settled and 
well-accepted, and therefore are properly characterized as rules of customary international law. ${ }^{130}$

Adjudicatory proceedings form only a small part of overall administrative action. ${ }^{131}$ The United States has emphasised the importance of the limitation of denial of justice claims to adjudicatory proceedings:

Apotex's reliance on CAFTA-DR is similarly misguided. Apotex notes that, in CAFTA-DR, “'fair and equitable treatment' includes the obligation not to deny justice in criminal, civil, or administrative adjudicatory proceedings in accordance with the principle of due process embodied in the principal legal systems of the world." Again, Apotex improperly extrapolates from a rule governing administrative adjudicatory proceedings - which connotes a formal process for dispute-resolution with a general rule governing all administrative decision-making. ${ }^{132}$

The NAFTA governments have also interpreted the denial of justice rule as requiring a systemic failure, not just a failure at one step of the legal process. It requires "proof that the national system was given a reasonably full chance to correct the unfairness in question. [I]nternational law does not impose a duty on states to treat foreigners fairly at every step of the legal process. The duty is to create and maintain $a$ system of justice which ensures that unfairness to foreigners either does not happen, or is corrected". ${ }^{133}$

Mexico has pointed to significant risks of forum shopping and numerous claims if the strict customary international law standard for establishing a denial of justice is relaxed:

$130 \quad$ Loewen, Mexico Second Non-Disputing Party Submission, pp. 2-3.

131 In subsequent treaties, the US and other governments have similarly specified the content of the MST-FET rule of denial of justice. For example, in the Korea-US Free Trade Agreement, it is specified that "' fair and equitable treatment' includes the obligation not to deny justice in criminal, civil, or administrative adjudicatory proceedings in accordance with the principle of due process embodied in the principal legal systems of the world". See Korea-US Free Trade Agreement, art. 11.5(2)(a); see also, e.g., CAFTA-DR art. 10.5(2)(a) (same); Chile-US FTA, art. 10.4(2)(a) (same). Mexico has referred to denial of justice in identical terms in the recent Pacific Alliance Protocol Agreement (with Chile, Columbia and Peru). See Pacific Alliance Protocol Agreement, art. 10.6(2)(a) ("'trato justo y equitativo' incluye la obligación de no denegar justicia en procedimientos penales, civiles o contencioso administrativos, de acuerdo con el principio del debido proceso incorporado en los principales sistemas legales del mundo"). Mexico has also referred to denial of justice in identical terms in recent treaties while clarifying that the MST-FET standard is not limited to denial of justice. See Mexico-Central America FTA, art. 11.3(2)(a) ("trato justo y equitativo" incluye, pero no está limitado a, la obligación de no denegar justicia en procedimientos penales, civiles o contencioso administrativos, de conformidad con el principio de debido proceso incorporado en los principales sistemas legales del mundo"). Apotex Holdings, US Counter-Memorial, § 371 (footnotes omitted) (emphasis in original).

Glamis, US Counter-Memorial, p. 247 n.1074 quoting Jan Paulsson, Denial of Justice in International Law 7-8 (2005) (emphasis in original). See also Pope \& Talbot, Mexico Third Non-Disputing Party Submission, p. 6 ("Mexico concurs with Canada that where domestic procedures exist for an investor to have complaints concerning administrative action dealt with fairly by an independent domestic tribunal, an investor cannot claim breach of Article 1105 if it has failed to avail itself of such available domestic remedies: The objective of an analysis under the minimum standard of treatment provision is to determine whether Canada's legal system as a whole has afforded the Investor treatment in accordance with international law. If Canada has done so, the Investor has no complaint and the Article 1105 inquiry is at an end."); Loewen, Mexico Second Non-Disputing Party Submission, p.7 ("Actions which fit within the category of public acts from which appeals on juridical grounds is provided in law, cannot be treated in isolation; the entire juridical structure must be considered in order to determine whether fair and equitable treatment has been accorded.”) 
There is a danger that if the strictness of the customary international law standard for establishing a denial of justice is relaxed, would-be claimants may see great advantage in forswearing the rigors of local remedies, preferring instead to impugn the acts of lower courts on the basis of subjective considerations of fairness and equity. In Mexico's respectful submission, there is a greater risk of such forum-shopping than may have been suggested during the hearing. Mexico shares Judge Mikva's view that the possibility that a claimant could invoke NAFTA State responsibility for any lower court decision, without more, would have "awesome" implications. It would be extraordinary and, in Mexico's view, unintended, if the NAFTA Parties had created a mechanism by which reviewable decisions of the lowest courts immediately could be elevated to the international level. In Mexico's view, the continued availability of domestic relief is always relevant in determining whether an international wrong and hence State responsibility can be established. ${ }^{134}$

Perhaps because denial of justice is often considered to set a strict and high standard, investors have rarely cited it as a rule they rely on their submissions under FET. Instead, they typically rely on a series of other alleged norms.

\section{Legitimate expectations}

Although the text of investment treaties rarely if ever refers to the protection of legitimate expectations, legitimate expectations have frequently been treated as a basis for liability in ISDS outside of NAFTA. The doctrine is perhaps the most prominent example of the claimed rapid development of a firm rule in investment treaty law (at least under FET provisions seen as being autonomous). The views of NAFTA governments about MST-FET contrast sharply with this view.

Canada and the United States have repeatedly rejected as unfounded investor claims that the MST-FET incorporates a rule protecting a foreign investor's legitimate expectations. More specifically, they have rejected claims that the MST-FET contains a rule providing a right to a stable legal environment. They have also rejected an alleged rule protecting investor expectations based on government assurances or commitments.

While both governments exclude any rule requiring protection of legitimate expectations, they have expressed differing positions on whether an investor's expectations are even relevant as a factor to be considered in MST-FET. The United States considers that no demonstration of relevance has been made based on the two elements of customary international law. As noted above, Canada shares the general view that MST-FET rules must be demonstrated based on the two elements. However, in some contexts it has stated that legitimate expectations based on specific commitments may be a relevant factor to be considered under certain conditions, albeit without examining state practice or opinio juris on the point.

a.

MST-FET does not include a rule protecting legitimate expectations

Both Canada and the US have repeatedly stated that there is "no general and consistent State practice and opinio juris establishing an obligation under the minimum standard of treatment not to frustrate investors' "expectations." " 135 They have rejected efforts by claimants to rely on arbitral decisions on FET or MST-

\footnotetext{
134 Loewen, Mexico Second Non-Disputing Party Submission, pp. 6-7 (footnotes omitted).

135 Mesa, Canada Response to Non-Disputing Party Submissions, § 12 (quoting Mesa, US Second NonDisputing Party Submission, § 18); Glamis, US Rejoinder, p. 178 (“Frustration Of An Investor's
} 
FET that do not examine state practice and opinio juris. For example, Canada recently stated that "the Claimant cannot turn to the decisions of international tribunals as evidence of State practice that the protection of an investor's expectations is required by the customary international law minimum standard of treatment." 136

In addition to stating that claims for breach of legitimate expectations lack support in State practice and opinio juris, the US has emphasised that allowing such claims would give rise to many claims and that the number could exceed those for breach of contract:

The consequences of agreeing with Glamis that mere frustration of a foreign investor's legitimate expectations rises to the level of a customary international law violation would be momentous. The volume of claims for frustration of expectations could far exceed those for breach of contract. Consider, by comparison, how vast municipal law liability would be if governments could be sued for merely frustrating expectations. U.S. law, not surprisingly, provides no cause of action for dashed expectations. ${ }^{137}$ (citation omitted)

b. MST-FET does not obligate governments to provide a stable legal environment

The United States has regularly reaffirmed that as a matter of international law, although an investor may develop its own expectations about the legal regime that governs its investment, those expectations do not impose a legal obligation on the State:

Claimants submit no evidence of State practice establishing a legal obligation not to frustrate an investor's expectations formed at the time the investor made its investment. State practice, in fact, tends to support the opposite view. As Claimants acknowledge, under customary international law, States may regulate to achieve legitimate objectives to benefit the public welfare and will not incur liability solely because the change interferes with an investor's "expectations" about the state of the business environment. The protection of public health falls squarely within that regulatory authority under international law. ${ }^{138}$

Canada has similarly interpreted MST-FET as excluding an obligation to provide a stable regulatory framework:

If it were true that customary international law required States to refrain from regulating in a way that frustrated the expectations of foreign investors, it would be impossible for States to regulate at all. The same

Expectations Does Not Give Rise To State Responsibility Under Customary International Law”) (bold in original).

Mesa, Canada Response to Non-Disputing Party Submissions, § 12.

$137 \quad$ Glamis, US Rejoinder, p. 182.

138 Grand River, US Counter-Memorial ,p. 99; Glamis, US Rejoinder, p. 178 (“Frustration Of An Investor's Expectations Does Not Give Rise To State Responsibility Under Customary International Law") (bold in original); Mesa, US Non-Disputing Party Submission, $\S 8$ ("States may modify or amend their regulations to achieve legitimate public welfare objectives and will not incur liability under customary international law merely because such changes interfere with an investor's "expectations" about the state of regulation in a particular sector.") (footnote omitted). 
can be said for the assertion that States are bound by custom to provide "stable regulatory framework" for foreign investors. ${ }^{139}$

c. MST-FET does not protect investor expectations based on government assurances or commitments

Canada and the United States interpret MST-FET as excluding any alleged rule based on an obligation to protect investor expectations based on assurances or commitments. The interpretation is based on several points. First, as elsewhere, the governments point out that claimants have failed to establish the customary international law elements supporting the rule and that arbitral decisions that do not address those elements are not relevant.

Canada and the US go further and view state practice as supporting the opposite conclusion. First, they note that a contract provides a much stronger basis for investor expectations than assurances or commitments by an official. A contracting party has a strong claim to and expectation of contract performance by the other party. Normally, each party has promised value in exchange as part of the contract. Accordingly, a breach of contract would be a stronger basis for a claim of frustrated expectations than a less express commitment, such as comments or encouragement to invest by a government official.

Second, they rely on state practice recognising that a contract breach by a government is not a violation of MST-FET:

It is well-settled, and has long been the position of the United States, that a State cannot be held to have violated the minimum standard upon a showing of mere breach of a contract with a foreign investor. [footnote 703]

Footnote 703: See SGS Société Générale de Surveillance S.A. v. Pakistan, ICSID Case No. ARB/01/13, Decision on Jurisdiction II 167 (Aug. 6, 2003) (noting "the widely accepted principle . . . that under general international law, a violation of a contract entered into by a State with an investor of another State, is not, by itself, a violation of international law"); SGS Société Générale de Surveillance S.A. v. Philippines, ICSID Case No. ARB/02/6, Decision on Jurisdiction II 122 (Jan. 29, 2004) (citing

Mobil, Canada, Counter-Memorial, § 268; see also Chemtura, Canada Rejoinder, § 192-93 ("The Claimant has failed to demonstrate that customary MST includes protection of an investor's "legitimate expectations" of a stable and predictable legal and business framework. Rather than evidence of State practice or opinio juris, the Claimant has instead pointed to the Tecmed decision and to arbitral awards relying on this award.... As Canada has noted, arbitral decisions do not themselves create customary international law.").

Mexico does not appear to have taken a position on this point although more research is necessary. Not all of its submissions are public. In Cargill v. Mexico, the tribunal considered that no evidence of such a rule had been provided. It rejected reliance on arbitral awards based on FET clauses interpreted as autonomous. See Cargill, Award, $§ \S 289-90$ ("Claimant provides the Preamble to the NAFTA as its sole legal or textual support for its contention that NAFTA State Parties are bound to provide a stable and predictable environment in which reasonable expectations are upheld. The Tribunal notes that there are at least two BIT awards, both involving a clause viewed as possessing autonomous meaning, that have found an obligation to provide a predictable investment environment that does not affect the reasonable expectations of the investor at the time of the investment. No evidence, however, has been placed before the Tribunal that there is such a requirement in the NAFTA or in customary international law, at least where such expectations do not arise from a contract or quasi-contractual basis.") (citations omitted). It is not clear if this reflects acceptance of a Mexican view on the point. 
SGS v. Pakistan with approval); Draft Articles on Responsibility of States for Internationally Wrongful Acts Adopted by the Drafting Committee on Second Reading, art. 4, cmt. If 6, International Law Commission, 53d Sess. (2001) ("Of course the breach by a State of a contract does not as such entail a breach of international law."); F.V. García-Amador, Special Rapporteur, International Responsibility: Fourth Report, U.N. Doc. A/CN.4/119 (Feb. 26, 1959), in 1959 Y.B. INT'L L. COMM'N, vol. II 9 123 ("Diplomatic practice and international case-law have traditionally accepted almost as dogma the idea that the mere non-performance by a State of its obligations under a contract with an alien individual does not in itself necessarily give rise to international responsibility."); F. A. Mann, State Contracts and State Responsibility, 54 AM. J. INT'L L. 572, 578 (1960) (pointing out that no States other than Switzerland and France have adopted the view that mere contractual breaches give rise to a breach of international law and that the United States "has, for more than a century and a half, been clearly opposed to it"). ${ }^{140}$

Canada has similarly stated that "a failure to fulfil a contractual promise is not a breach of customary international law". ${ }^{141}$

Canada and United States conclude that because the disappointed expectations resulting from a contract breach do not violate the MST-FET standard, disappointment arising from expectations that have a weaker basis than contract does not establish a violation of MST-FET:

To suggest, then, that Article 1105 provides a basis for an investor to submit a claim under Chapter Eleven for mere frustration of a legitimate expectation is nonsensical. If breach of contract - which also necessarily frustrates expectations - is not protected by the minimum standard of treatment, certainly frustrated expectations in the absence of such an express commitment cannot give rise to a violation of that standard. Glamis offers no evidence that - or rationale why - international law would not recognize mere breach of a contract as wrongful, but would find cognizable disappointment of an investor's expectations based on a lesser form of assurance. ${ }^{142}$

The US and Canada also point to States' practice of negotiating specific provisions in treaties to make contracts with governments enforceable under the treaty. ${ }^{143}$ These include clauses making "investment agreements" or contracts enforceable and possibly to some interpretations of umbrella clauses that extend to contracts. The US has pointed out that such provisions would be superfluous if governments considered that legitimate expectations were protected under MST-FET:

\footnotetext{
$140 \quad$ Glamis, US Rejoinder, p. 179 \& n.703.

$141 \quad$ Mobil, Canada Rejoinder, $\$ 149$.

142 Glamis, US rejoinder, n. 706; see also Mobil, Canada Rejoinder, § 149 ("Since a failure to fulfil a contractual promise is not a breach of customary international law then the failure to fulfil a lesser form of assurance which generates a legitimate expectation certainly is not.").

143 For a recent example, see, e.g., China-Japan-Korea art. 5(2) ("Each Contracting Party shall observe any written commitments in the form of an agreement or contract it may have entered into with regard to investments of investors of another Contracting Party.")]
} 
If ... the fair and equitable treatment standard proscribed the mere frustration of legitimate expectations, such provisions would be superfluous. A breach of an "investment agreement" is but a type of frustrated legitimate expectation - albeit one characterized by a robust form of assurance. No "investment agreement" provision would actually be needed if a claimant could state a claim under the fair and equitable treatment article for frustration of its legitimate expectations. ${ }^{144}$

d. Are legitimate or reasonable expectations based on assurances a factor that can be taken into account under some conditions under MST-FET?

The US has stated that legitimate or reasonable expectations are relevant to claims of indirect expropriation, but are not part of the framework of analysis of MST-FET. For example, the US has stated that reasonable expectations are part of the analysis for indirect expropriation, but "the context of the fair and equitable treatment analysis ... is not the appropriate framework for the reasonable expectations analysis". ${ }^{145}$ As noted above, the US has stated that only a few rules have been established as existing under the MST-FET. The MST-FET rules that the US recognises, such as the obligation not to deny justice, would appear in any event to leave little scope for consideration of expectations.

In some submissions, Canada has suggested that legitimate expectations based on specific assurances could be a factor in MST-FET claims, but only under strict conditions. In a recent submission, Canada indicated that possible relevance depends on the fulfillment of several conditions:

In order for any of their expectations to be at all relevant context to assessing whether or not the conduct in question here rises to the level of a breach of Article 1105, the Claimants must prove that their expectations (1) arose from a specific assurance made by Canada, (2) made in order to induce their investment at Whites Point (i.e. it must have been made before the investment was made), and (3) that their expectations were objective rather than subjective. ${ }^{146}$

144 Glamis, US Rejoinder, p. 181. Canada has also pointed this out. See Mobil, Canada Rejoinder, § 148 (the conclusion that breach of contract does not create state responsibility on the international plane "is also consistent with the inclusion in many bilateral investment treaties of both 'umbrella clauses', which tribunals have found to elevate breaches of contract to a breach of the treaty, and clauses which give investors the right to bring a claim for breach of an 'investment agreement'. If breach of contract was a breach of the obligation to provide fair and equitable treatment then there would be no need to include such clauses in the treaty.")

Canada has also stated that where a contract breach is accompanied by something "more" that gives rise to an international law violation, it is the something more that is the source of violation rather than the disappointed expectations. Mobil, Canada Rejoinder $\S 151$ ("If customary international law requires specific circumstances such as expropriation for a breach of contract to amount to a breach of customary international law then the absence of these circumstances establishes that there is no such breach.")

$145 \quad$ See, e.g., Glamis, US Rejoinder, p. 97 \& n.389.

146 Bilcon, Canada Counter-Memorial, § 392; see also Mesa, Canada Rejoinder, § 158 ("However, for any of the Claimant's "expectations" to be a relevant factor, the Claimant must demonstrate that it had objective expectations which arose from specific assurances made by Canada and which actually induced it to make its investments. Further, as the Feldman Tribunal explained, for expectations to be relevant, the government assurances have to be definitive, unambiguous, repeated, and given by an entity that had the authority to do so.") (citations omitted). 
The US has stated that the relevance of investor expectations to the MST-FET has not been established under customary international law. It recently rejected the reasoning of the Bilcon tribunal on this basis:

[T] he [Bilcon] tribunal improperly concluded that "[t]he reasonable expectations of the investor are a factor to be taken into account in assessing whether the host state breached the international minimum standard of treatment of fair and equitable treatment under Article 1105 of NAFTA." Because the Bilcon tribunal cited no State practice or opinio juris for this finding, it was erroneous to conclude that "reasonable expectations" are part of the customary international law minimum standard of treatment. ${ }^{147}$

\section{4. $\quad$ Arbitrariness}

NAFTA does not contain an express provision addressing arbitrary conduct. NAFTA governments have addressed whether arbitrary conduct is covered by the MST/FET provision. Arbitrariness is a broad concept. This section sets out some initial findings but, as in other areas, further research is required.

a.

No general MST-FET liability for arbitrary conduct

Canada and the US have rejected claims that the MST-FET provision imposes a general obligation on States to refrain from arbitrary conduct. Canada has thus objected to attempts "to introduce ... new obligations into the NAFTA [including] ... the obligation to provide treatment free from arbitrary ... conduct". ${ }^{148}$ The US has similarly rejected attempts to establish "a vague, general international obligation to refrain from 'arbitrary' or 'bad faith' conduct." 149

Canada has stated that while there is no prohibition of arbitrary conduct under customary international law, arbitrary conduct can be relevant if invoked in connection with a claim of breach of a rule that does form part of customary international law, such as denial of justice:

If resorted to in connection with interpretation or application of a rule of customary international law - such as "denial of justice" - that forms part of the minimum standard the concept of arbitrary and discriminatory conduct could indeed be relevant. But ... it is not a rule in itself. It is not an independent source of legal obligation. ${ }^{150}$

b. The ELSI case

Mexico has referred to the ICJ decision in $E L S I^{151}$ as an expression of the standard of arbitrariness. ELSI referred to arbitrariness in the following terms:

\footnotetext{
147 Mesa, US Second Non-Disputing Party Submission, § 18.

$148 \quad$ Merrill, Canada Counter-Memorial, § 486.

149 See $A D F$, US Final Post-Hearing Submission, p.7 (); Glamis, US Counter-Memorial, p. 227 (“Glamis has also failed to present any evidence of relevant State practice to support its contention that Article 1105(1) imposes a general obligation on States to refrain from "arbitrary" conduct.").

$150 \quad$ UPS, Canada Counter-Memorial, § 928.

151 Elettronica Sicula S.p.A. (ELSI) Case (United States of America v. Italy) [1989] ICJ Rep. p.15.
} 
Arbitrariness is not so much something opposed to a rule of law, as something opposed to the rule of law. This idea was expressed by the Court in the Asylum case, when it spoke of 'arbitrary action' being 'substituted for the rule of law' (Asylum, Judgment, I.C.J. Reports 1950, p. 284). It is a wilful disregard of due of law, an act which shocks, or at least surprises, a sense of judicial propriety. ${ }^{152}$

Mexico has recognised that ELSI involved a treaty, but has stated that it considers that ELSI was addressing arbitrariness under customary international law. It has interpreted ELSI as establishing a very high standard and rejected the suggestion by the Pope \& Talbot tribunal that ELSI had relaxed the standard. ${ }^{153}$ The US has rejected the use of ELSI as a basis for a customary international law rule on arbitrariness because the case involved a bilateral treaty with a specific provision on arbitrary conduct. The case accordingly involved interpretation of a treaty standard rather than customary international law. ${ }^{154}$

c. Manifest arbitrariness

The US recently stated that regulatory action violates MST-FET where it constitutes "manifest" arbitrariness falling below international standards. ${ }^{155}$ As background for its brief statement on this point, it cited in part its extensive submissions in Glamis. ${ }^{156}$ Canada has referred to previous tribunals stating that manifest arbitrariness is a violation of MST-FET. ${ }^{157}$ In some cases, references by Canada to manifest arbitrariness appear primarily to address the threshold of seriousness needed for a violation rather than the question of whether arbitrariness is a stand-alone rule under MST-FET. ${ }^{158}$ The elements of customary international law have not been addressed with regard to manifest arbitrariness. Given the potential breadth of the concept in applying to both procedural and substantive matters, analysis of the elements of customary international law may be required to determine its scope as seen by the NAFTA governments.

\section{Discrimination}

The 2001 Joint Interpretation expressly rejected the view in a prior arbitration award that a violation of the national treatment provision was also a violation of MST-FET. Some claimants continue to invoke alleged discrimination as part of their arguments under MST-FET.

The US considers that the relevance of discrimination in art. 1105(1) is narrow. To the extent that the customary international law minimum standard of treatment incorporated in Article 1105 prohibits discrimination, it does so in the context of other established, customary international law rules:

As a legal matter, Claimants' assertion that Article 1105(1) contains an open ended prohibition on discrimination against aliens is unsupported. Because the NAFTA Parties specifically prohibited discrimination against

\footnotetext{
152 UPS, Mexico Fourth Non-Disputing Party Submission, § 15 \& n.9 quoting Elettronica Sicula S.p.A. (ELSI) Case (United States of America v. Italy) [1989] ICJ Rep at para. 128.

$153 \quad A D F$, Mexico Second Non-Disputing Party Submission, pp. 16-18.

154 Glamis, US Counter-Memorial, p. 228.

155 Mesa, US Non-Disputing Party Submission, $\$ 8$.

$156 \quad$ Id. $\$ 8 \&$ n. 10 .

$157 \quad$ Eli Lilly, Canada Counter-memorial $§ 213$.

158 See, e.g., Gallo, Canada Statement of Defence, § 182; Mobil, Canada Counter-Memorial, § 246 (both appearing to address primarily the threshold for a violation).
} 
foreign investors and their investments in particular provisions of Chapter Eleven, and did not include an express prohibition against discrimination in Article 1105(1), that provision should not be read to include an openended prohibition on discrimination against foreign investments. To the extent that the customary international law minimum standard of treatment incorporated in Article 1105 prohibits discrimination, it does so in the context of other established, customary international law rules, including the prohibitions against denials of justice and unlawful expropriation, as well as the obligation of full protection and security. ${ }^{159}$

Mexico has contrasted treaty-based and customary international law rules on discrimination. It considers that treaty-based rules are more demanding. Customary international law allows for more favourable treatment of nationals while proscribing "base discrimination":

[T] he customary international law rules are not to be confused with conventional international legal rules which, by contrast, are more specifically worded. For example, the conventional obligation of national treatment expressed in Article 1102 goes much further than the customary international law rule prohibiting discriminatory treatment of aliens. The customary international law standard proscribes base discrimination while permitting more favorable treatment of nationals in comparison to aliens, while the treaty standard of national treatment requires the State to engage in more substantial equality of treatment than that required at customary international law. ${ }^{160}$

Canada has objected to attempts "to introduce ... new obligations into the NAFTA [including] ... the obligation to provide treatment free from ... discriminatory conduct". ${ }^{161}$ It has noted that the NAFTA Parties' decision to address discrimination in specific terms in other articles of the treaty. It has stated that no rule of customary international law exists that would prohibit a State from differentiating between nationals and aliens:

No stand-alone or independent obligation prohibiting "discrimination" exists under Article 1105(1). NAFTA Chapter Eleven includes a comprehensive and specific legal regime governing nationality-based discrimination. Discrimination is covered by Articles 1102 to 1104 , not Article $1105(1)$.... In any event, there exists no rule of customary international law that prohibits a State from differentiating between nationals and aliens. ${ }^{162}$

6.

Transparency

All three NAFTA governments have stated that transparency is not part of MST-FET. Canada has rejected attempts to use arbitral awards to establish such an obligation:

\section{Transparency is not part of customary MST}

\footnotetext{
$159 \quad$ Grand River, US Counter-Memorial, p. 126.

$160 U P S$, Mexico Fourth Non-Disputing Party Submission, § 16.

$161 \quad$ Merrill, Canada Counter-Memorial, § 486.

162 Merrill, Canada Counter-Memorial, $\S \S 502,505$.
} 
In its Memorial, the Claimant argues that the requirement of "total transparency" set out by the Tecmed Tribunal is the applicable standard, and has reiterated in its Reply that the Teemed award "continues to be cited with approval by arbitral tribunals".

The Claimant has failed to demonstrate that "transparency" forms part of customary MST. The Claimant has provided no evidence either of State practice, or of opinio juris to this effect. Accordingly, its argument to this effect must fail. ${ }^{163}$

Mexico has similarly rejected any obligation of transparency under MST-FET. Mexico has underlined that where transparency obligations exist, they are adopted expressly by treaty. ${ }^{164}$ The US has also stated that customary international law does not impose any transparency requirements on governments. ${ }^{165}$

7.

Good faith

Canada and the US have rejected good faith as a stand-alone element of customary MST. "As Canada noted in its Counter-Memorial, good faith as a general principle of international law dictates the manner in which an existing obligation should be fulfilled, rather than being a source of obligation in its own right." 166 Similarly, the US has stated that "[t]he principle of 'good faith' ... is not a separate element of the minimum standard of treatment embodied in the Agreement. It is well established in international law that good faith is 'one of the basic principles governing the creation and performance of legal obligations,' but 'it is not in itself a source of obligation where none would otherwise exist.",167

8.

Fairness

As noted above, the 2001 binding Joint Interpretation by the NAFTA Parties was in part a reaction to the suggestion by the Pope \& Talbot tribunal that art. 1105 contained "fairness elements" in addition to the MST-FET. The NAFTA parties have regularly rejected suggestions that the MST-FET permits a general inquiry about fairness. An arbitral decision in 2010 in Merrill \& Ring again suggested that art. 1105(1) gives rise to a general arbitral inquiry about "fairness, equity and reasonableness", suggesting that this inquiry is part of MST-FET. ${ }^{168}$ The three NAFTA governments have rejected this view, underlining that it has no basis in state practice or opinio juris:

The Merrill \& Ring tribunal cited no State practice or opinio juris to support its conclusion. See Patrick Dumberry, The Fair and Equitable

\footnotetext{
163 Chemtura, Canada Rejoinder, p. 69.

164 See, e.g., Cargill, Mexico Duplica, $\S 128$.

165 See Glamis, US Rejoinder p. 155 ("No Transparency Rule Is Required By The International Minimum Standard Of Treatment Reflected In Article 1105(1)") (bold in original)

166 Chemtura, Canada Rejoinder, $\S 187$; id. p. 68 (“Good faith is not an independent element of customary MST") (bold in original).

$167 \quad$ Mesa, US Non-Disputing Party Submission, $§ 7$ (footnotes omitted).

168 Merrill, Final Award, $\S 210$ ("A requirement that aliens be treated fairly and equitably in relation to business, trade and investment is the outcome of this changing reality and as such it has become sufficiently part of widespread and consistent practice so as to demonstrate that it is reflected today in customary international law as opinio juris. In the end, the name assigned to the standard does not really matter. What matters is that the standard protects against all such acts or behavior that might infringe a sense of fairness, equity and reasonableness.").
} 
Treatment Standard: A Guide to NAFTA Case Law on Article 1105 at 115 (2013) (observing that the tribunal failed "to cite a single example of State practice in support of" its "controversial findings") (emphasis in original); UNCTAD, FaIR and Equitable TREatMENT - UNCTAD SERIES ON IsSUES IN INTERNATIONAL AgreEMENTS II at 57 (2012) ("The Merrill \& Ring tribunal failed to give cogent reasons for its conclusion that MST made such a leap in its evolution, and by doing so has deprived the 2001 NAFTA Interpretive Statement of any practical effect."). The tribunal's statement, therefore, is the erroneous opinion of a single ad hoc tribunal and has no relevance for determining the content of customary international law in general or of Article 1105(1) in particular.") ${ }^{169}$

\section{The substance of the NAFTA MST-FET provision is not altered by the most-favoured nation (“MFN") provision in NAFTA}

The NAFTA parties have a variety of investment treaties with third countries that also contain FET provisions. In some cases, these provisions have somewhat different wording than NAFTA art. 1105. NAFTA also contains an MFN provision in Chapter 11. NAFTA art. 1103 extends MFN protection to investors and investments. With regard to investment treaties, only treatment accorded under post-NAFTA treaties is subject to MFN. ${ }^{170}$

Investors in a number of NAFTA cases have sought to rely on the MFN provision in NAFTA to incorporate FET provisions in post-NAFTA treaties between NAFTA countries and third States that the investors claim provide broader protection than NAFTA art. 1105(1). For example, investors have sought to rely on Canadian post-NAFTA BITs that oblige each BIT party to "accord investments or returns of investors of the other Party fair and equitable treatment in accordance with international law" (or "principles of international law"). ${ }^{171}$ They have also sought to rely on US post-NAFTA BITs that provide that "[e]ach Party shall at all times accord to covered investments fair and equitable treatment ..., and shall in no case accord treatment less favourable than that required by international law". ${ }^{172}$

NAFTA governments have stated that the substance of the NAFTA MST-FET provision is not altered by the MFN provision in NAFTA. ${ }^{173}$ The three NAFTA parties have agreed that NAFTA cannot operate so as

169 Mesa, US Second Non-Disputing Party Submission, p. 6, n.23. See Mesa, Canada Observations on Award, $\S 17$ ("the decision of the tribunal in Merrill and Ring $v$. Canada, do[es] not conduct the required analysis of customary international law"). ${ }^{169}$; see also Mesa, Mexico Second Non-Disputing Party Submission, $\$ 10$ ("Mexico concurs with Canada's submission that decisions of arbitral tribunals are not themselves a source of customary international law and that the Bilcon tribunal's reliance on Merrill \& Ring was misplaced. The Merrill \& Ring tribunal's obiter dicta on the interpretation and application of NAFTA Article 1105 fails to reflect a proper analysis of customary international law.").

170 The NAFTA Parties took an exception to Article 1103 for treatment accorded under all bilateral or multilateral international agreements in force or signed prior to the date of entry into force of NAFTA. See NAFTA Annex IV: Exceptions from Most-Favored-Nation Treatment (Schedules of Canada, Mexico and United States).

171 See Chemtura, Canada Counter-Memorial, § 892.

172 See, e.g., ADF, Award, $\$$ 77-78 (citing Albania-US BIT).

173 The fact-finding here is limited to views about the FET provisions. NAFTA governments have stated that the MFN provision in NAFTA does not apply to incorporate treaty standards such as FET from other treaties. See, e.g., Chemtura, Canada Counter-Memorial, § 906 ("The MFN obligation in Article 1103 is a limited one that applies to treatment, and does not bring treaty standards into NAFTA"); $A D F$, US Rejoinder, p. 44 n.69; Mesa, Mexico Non-Disputing Party Submission, § 13 ("Mexico disagrees with the 
to create a conflict between art. 1103 and a binding joint interpretation of the FET provision in the treaty; the binding interpretation sets out the governing law. US non-disputing party submissions have quoted submissions by Canada, with which both Mexico and US expressly concurred, that (i) "Article 1103 can no longer be relevant or constitute an issue with respect to the interpretation of Article 1105, as the interpretation of the latter is set out in the Note of Interpretation, which is binding on the Tribunal"; and (ii) "Article 1131(2) interpretations bind tribunals in stating the governing law, and the NAFTA cannot operate so as to create a conflict between Article 1103 and the interpretation." 174

Canada and the US have also stated that their post-NAFTA treaties establish the same MST-FET provision limited to customary international law as in NAFTA art. $1105 .{ }^{175}$ Canada has stated that "[t]here is no difference in the standards of treatment afforded under NAFTA Article 1105 (as reaffirmed in the Note of Interpretation) and the post-NAFTA BITs -- both accord the customary international law minimum standard of treatment." ${ }^{176}$ The US has stated that its FET provisions in its treaties with other States also reference customary international law obligations and do not provide greater protection than NAFTA art. $1105(1) .{ }^{177}$

The US and Canada have also pointed to internal documents interpreting the post-NAFTA treaties. The US has referred to repeated advice by the US State Department to the US Senate over many years that the BIT paragraph in the post-NAFTA treaties referred to by investors containing the provisions concerning fair and equitable treatment is intended only to require a minimum standard of treatment based on customary international law. ${ }^{178}$ Canada has noted that its website referred to the treaties with third states as NAFTA-based agreements. ${ }^{179}$

suggestion in ... Claimant's Reply Memorial that Article 1103 can be used to import language into the NAFTA from the Canada-Czech investment Treaty").

See Chemtura, US Non-Disputing Party Submission, §§ 6-8 (citing, inter alia, Pope \& Talbot, Inc. v. Canada, NAFTA/UNCITRAL, Letter from [Canadian counsel] M. Kinnear to Tribunal, Oct. 1, 2001, at 34 (emphasis added); Pope \& Talbot, Inc. v. Canada, NAFTA/UNCITRAL, Letter from [Mexican counsel] H. Perezcano Díaz to Tribunal, Oct. 1, 2001, at 1 (emphasis added); Pope \& Talbot, US Sixth NonDisputing Party Submission (Corrected), § 2 (emphasis added); see also Mesa, US Non-Disputing Party Submission, $\S 10$ (expressly incorporating the views set out in the submission in Chemtura).

See, e.g., $A D F$, US Rejoinder, p. 40 ("ADF errs in suggesting that the standards of the [FET] provisions it invokes in the United States' BITs with Albania and Estonia are different from the customary international law standards incorporated into Article 1105(1).").

See, e.g., $A D F$, US Rejoinder, p. 42 ("The United States' view that "fair and equitable treatment" ... references customary international law obligations accords with consistent State practice concerning the content of [that] term[]. From the use of those terms in the 1967 OECD Draft Convention on the Protection of Foreign Property to the present, State practice has consistently viewed "fair and equitable treatment" as referring to the customary international law minimum standard of treatment of aliens. Thus, State practice supports the view that "fair and equitable treatment," as used in investment treaties, refers to the customary international law minimum standard of treatment of aliens.").

See e.g., $A D F$, US Rejoinder, p. $41 \mathrm{nn}$. 59-61 (citing numerous letters from the State Department including Dep't of State, Letter of Submittal for U.S.-Albania Treaty Concerning the Encouragement and Reciprocal Protection of Investment, reprinted in S. Treaty Doc. No. 104-19 at vii (1995) ("Paragraph 3 sets out a minimum standard of treatment based on standards found in customary international law. The obligations to accord 'fair and equitable treatment' and 'full protection and security' are explicitly cited .....")). 


\section{PRELIMINARY OBSERVATIONS}

While more research and analysis are required, it may be useful to set out some tentative initial observations in two areas: (i) the striking differences between MST-FET as seen by NAFTA governments and FET as seen by some ISDS tribunals and commentators; and (ii) NAFTA government success in defending cases and the question of whether tribunals apply the governments' interpretations.

\section{A. Differences between FET as seen by ISDS commentators and tribunals and MST-FET as seen by NAFTA governments}

1. The Alleged FET Lists of commentators and tribunals differ sharply from the view of MST-FET of the NAFTA governments

Even a cursory comparison of Alleged FET Lists that commentators or tribunals have generated from FET provisions reveals numerous differences with the views of the NAFTA governments. Collectively, it appears that the NAFTA governments have only clearly accepted denial of justice as a rule under the MSTFET standard. There is also some support for acceptance of a rule based on manifest arbitrariness although its basis in the elements of customary international law has not been explained. There is little in common between an MST-FET provision seen as encompassing one or two rules, and a FET provision that is seen as encompassing six to eight rules and a general obligation of fairness.

The different views about the content of FET between NAFTA government views of MST-FET and many ISDS arbitrators and commentators appear to be closely related to the different sources of the rules. The approach of most commentators and ISDS tribunals is focused primarily if not exclusively on arbitral decisions. For example, Dolzer's recent discussion of the contours of FET makes no reference to state practice or opinio juris. There is no reference to any government interpretation of the standard. The details of the "current state of the law" are derived solely from arbitral decisions. ${ }^{180}$ This type of approach obviously differs sharply from the insistence of NAFTA governments on proof of state practice and opinio juris.

Governments may wish to consider carefully how to address FET or possible substitutes in their treaties. Governments may wish to specifically define FET either by expressly limiting it to MST-FET and possibly providing additional guidance about the content of MST-FET, or by specifying the elements of FET. They may wish to avoid the use of the term in their treaties. Recent treaties that have defined the term have taken very different approaches. The China-ASEAN treaty defines FET as denial of justice, harkening closely to the views of some NAFTA governments. In contrast, CETA defines FET using five elements and a reference to possible consideration of certain legitimate expectations in some circumstances. The recent Indian Model treaty omits the term. The treaty protects covered investors from violations of customary international law involving specified elements.

For existing treaties, the situation also raises serious difficulties for governments attempting to evaluate the impact of FET on proposed or existing regulation. For example, a bare FET clause can be subject to widely different interpretations depending in part on whether it is interpreted as autonomous or as being limited to MST-FET.

180 See Rudolf Dolzer, Fair and Equitable Treatment: Today's Contours, 12 Santa Clara J. Int'l L. 7 (2014) at p. 20 ("In the light of the arbitral jurisprudence, the details of the current state of the law will be summarized ....”). 
2. $\quad$ Given the different content of MST-FET as seen by at least some major governments and FET as seen by tribunals, the arbitral decisions that suggest that MST-FET and autonomous FET have the same content are puzzling

Given the differences between MST-FET as seen by NAFTA governments and FET as seen by tribunals, it is equally striking to note that some recent ISDS tribunals have stated that the MST/FET standard and autonomous FET clauses are the same. In Deutsche Bank, for example, the tribunal "recognize[d]" in a single sentence that the "actual content of the Treaty standard of fair and equitable treatment is not materially different from the content of the minimum standard of treatment in customary international law, as recognised by numerous arbitral tribunals and commentators." "181 It cited several earlier arbitral decisions without explanation. Its view was not based on any review of the elements of state practice and opinio juris. Neither concept is mentioned.

The tribunal lists the components of its merged FET/MST-FET standard as follows:

- protection of legitimate and reasonable expectations which have been relied upon by the investor to make the investment;

- good faith conduct although bad faith on the part of the State is not required for its violation;

- conduct that is transparent, consistent and not discriminatory, that is, not based on unjustifiable distinctions or arbitrary;

- conduct that does not offend judicial propriety, that complies with due process and the right to be heard.

There is again a marked contrast between this list and NAFTA government views. The US and Canada have rejected legitimate expectations as a component of MST-FET; Mexico has expressed fewer views on that issue. All three governments appear to (i) reject good faith as a separate component; (ii) exclude any obligation of transparency; (iii) exclude a general prohibition of discrimination; and (iv) insist that the standard for breach is high.

It does not appear to be possible to reconcile these two very different views of MST-FET. They differ profoundly in method - reliance on state practice and opinio juris vs. reliance on arbitral cases. Under the NAFTA governments view, the tribunals view about MST-FET are not entitled to any weight unless they are based on state practice and opinio juris, the two elements of customary international law. Few tribunals have engaged in such an analysis in their decisions.

The rationale for tribunals' excluding consideration of easily-available state practice and opinio juris on MST-FET is less clear. ${ }^{182}$ The tribunals in the two cases cited above do not explain their theory of the identification of customary international law or why they rely solely on arbitral awards and commentary. For governments, the co-existence of such sharply different views about how MST-FET is identified and its content raises a number of issues.

181 See, e.g., Deutsche Bank AG v. Democratic Socialist Republic of Sri Lanka, Award, 31 October 2012, §§ 418-419 ("the actual content of the Treaty standard of fair and equitable treatment is not materially different from the content of the minimum standard of treatment in customary international law, as recognised by numerous arbitral tribunals and commentators"); SAUR International SA v. Republic of Argentina, Decision on Jurisdiction and Liability, §§ 491-494.

182 While state practice is sometimes hard to access, it is well-known that the NAFTA views are publicly available on government and commercial websites with search capacity. Parties to cases regularly cite NAFTA arbitral awards and the NAFTA governments cite government submissions. 
Most directly, it is of interest for the many countries that are incorporating express MST-FET provisions in major treaties. Such a provision may be construed to have a very different scope depending on whether the provision is interpreted in accordance with Deutsche Bank, the views of NAFTA governments or some other approach. This may explain why some governments are providing further guidance as to the content of MST-FET in their treaties, as in the TPP, other recent US treaties or the Pacific Alliance. ${ }^{183}$ It may also explain the omission of FET in some recent approaches. Another factor may be the extent to which the treaty parties articulate a common view in a particular case, a series of cases or in a joint interpretation.

More generally, sharply different approaches to interpretation in some cases may invite analysis of ISDS tribunals' approach to identifying customary international law. It is important first, however, to consider the views of additional governments with regard to MST-FET.

\section{B. NAFTA government success in claim outcomes and in obtaining tribunals' application of their interpretations of MST-FET}

As noted above, general statistics developed by UNCTAD as of 2010 showed a marked difference in government success rates for FET claims under NAFTA (78\%) and under other treaties (38\%). Those statistics include all cases including NAFTA cases filed before the 2001 Joint Interpretation clarifying that art. 1105(1) establishes the MST-FET standard.

Statistics for cases filed after the Joint Interpretation may show a still greater difference. Until the controversial 2015 Bilcon majority decision whose reasoning has been criticised by all three NAFTA governments, only one case filed after the Joint Interpretation had found a NAFTA government liable under MST-FET. The case involved deliberate intent to harm a covered investor. ${ }^{184}$

An important question is whether the different outcomes are due to different treaty provisions, and in particular to MST-FET, or to other factors. Many other factors may be relevant to degrees of success and the issue is not addressed here. It is noteworthy, however, that government officials have recently emphasised the importance of differences in treaty provisions to the protection of the right to regulate. In recent statements, US officials have pointed to what they see as substantial differences between the strong protection of the right to regulate in US treaties and many other treaties that do not meet the same standards:

The United States has been a leader in developing carefully crafted ISDS provisions to protect the ability of governments to regulate ....

These provisions are different - and stronger - than the provisions in many other investment agreements in which the United States is not a participant. It's important to understand how U.S. agreements differ from other agreements that do not meet the same standards. ...

\footnotetext{
183 In terms of content of the MST-FET standard, the only rule specifically listed under MST-FET in the TPP is the obligation not to deny justice in adjudicatory proceedings (TPP art. 9.6(2)). Denial of justice is sharply limited in domain compared to many arbitral interpretations of FET (e.g. applying only to adjudicatory proceedings rather than to all governmental legislative, regulatory and other action). Additional MST-FET norms beyond denial of justice are contemplated in the TPP. However, the TPP expressly clarifies that the foreign investor claimant's burden to prove all elements of its claim includes the burden to establish the existence of any asserted additional rule of customary international law through evidence of (i) state practice that (ii) states follow from a sense of legal obligation (opinio juris). (TPP, Annex 9-A; art. 9.22(7)).

See Cargill Inc. v. Mexico, Award (18 Sept. 2009) § 299.
} 


\section{Protect the right of governments to regulate in the public interest.}

The United States wouldn't negotiate away its right to regulate in the best interest of its citizens, and we don't ask other countries to do so either. Our investment rules preserve the right to regulate to protect public health and safety, the financial sector, the environment, and any other area where governments seek to regulate. ${ }^{185}$

A second area for analysis of relative success is the degree to which NAFTA government interpretations of the nature and content of MST-FET have been applied by NAFTA tribunals. This analysis is outside the scope of this initial paper focused on government interpretations. A number of monographs and treatises address arbitral decisions under NAFTA.

It is important to note, however, that whether governments can achieve success in this area has become part of the broader debate about ISDS and the balance between investor protection and the right to regulate. Advocates for ISDS reform, for example, have contended that even the vigorous attention of some governments to making clear that MST-FET must be defined by state practice and opinio juris has not been successful in restraining arbitral tribunals from relying solely on arbitral precedents in defining MST-FET standards under customary international law in some cases. ${ }^{186}$ Criticism has focused for example on a 2013 decision under CAFTA-DR, Railroad Development Corp. v. Guatemala ${ }^{187}$ Critics have complained that even clear provisions on MST-FET have been unable to break the reliance of ISDS tribunals on arbitral precedent:

In theory, linking FET to [customary international law ("CIL")] results in a standard of protection that is more deferential to the regulatory authority of governments than the EU's "autonomous" standard. A CIL-linked standard should also have greater legitimacy given that it is rooted in the actual practice of states that they believe to reflect their international legal obligations rather than simply the pronouncements of investment tribunals.

In practice, however, investment tribunals continue to construe even CILbased FET provisions to impose broad limits on government authority by accepting, without any evidence of state practice or opinio juris, the pronouncements of previous tribunals as definitive evidence of the

USTR, The Facts on Investor-State Dispute Settlement; See also Jeffrey Zients, Investor-State Dispute Settlement (ISDS) Questions and Answers, White House Blog (26 Feb. 2015) ("Th[e] thousands of [investment] agreements contain a wide range of standards, some that strongly protect a government's right to regulate, others that do not. The U.S. has been at the leading edge of updating, upgrading and clarifying these standards; protecting the right to regulate; and drawing lessons from previous agreements to ensure that our agreements have the highest possible standards. TPP incorporates and builds on those efforts and goes beyond them").

From another perspective, a well-known professor and arbitrator has argued that government "efforts to confine the exercise of arbitrators' judgment in each application of FET, especially by trying to anchor it to the minimum standard, are as futile as King Canute's attempt to control the tides ..." See W. Michael Reisman, Canute Confronts the Tide: States versus Tribunals and the Evolution of the Minimum Standard in Customary International Law, ICSID Review, Vol. 30, No. 3 (2015), pp. 616-634 at p. 616.

CAFTA-DR contains an MST-FET provision similar to NAFTA. The CAFTA-DR expressly states that MST-FET is to be determined based on state practice and opinio juris; it thus makes explicit the same government views about the identification of MST-FET as those of the NAFTA governments, as set forth above. 
standard under CIL. The award in Railroad Development Corp. $v$. Guatemala $(R D C)$ is an example of this approach, which renders the linkage of FET to CIL largely meaningless. The reluctance of investment tribunals to base their interpretations of CIL on actual state practice and opinio juris suggests that more aggressive approaches may be necessary to deter tribunals from adopting increasingly broad interpretations of FET. ${ }^{188}$

Critics also point to the lack of review for errors of fact or law in ISDS so that erroneously decided awards still stand.

As noted above, the NAFTA governments have similarly criticised the majority decision in the recent Bilcon case under NAFTA in 2015 for failing to properly address customary international law or for relying solely on arbitral precedent in addressing MST-FET. ${ }^{189}$ Other NAFTA cases, however, such as Cargill or Glamis, have engaged in significant review of state practice and opinio juris. ${ }^{190}$ Both treaty

188 Matthew C. Porterfield, A Distinction Without a Difference? The Interpretation of Fair and Equitable Treatment Under Customary International Law by Investment Tribunals (22 March 2013); see also, e.g., Public Citizen, Setting the Record Straight: Debunking Ten Common Defenses of Controversial InvestorState Corporate Privileges ("The important matter requiring redress in the TPP negotiations is that the RDC award shows that the "Customary International Law" annex, found in recent U.S. FTAs and proposed for inclusion in the TPP, has proved insufficient to limit tribunals from interpreting the current MST language to create expansive and arbitrary obligations for governments.") (bold in original); Sander Levin, TPP in Focus: Investment and Investor-State Dispute Settlement - The Need for

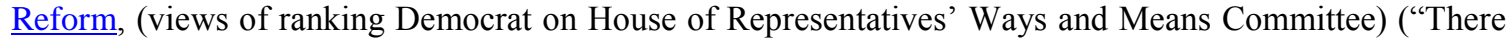
are also still concerns regarding the manner in which tribunals interpret U.S. investment agreements. For instance, tribunals have continued to construe the MST obligation in a broad fashion. ...[Certain] [d]ecisions suggest that tribunals require even further guidance on what the MST obligation actually means."). See also Patrick Dumberry, The Prohibition against Arbitrary Conduct and the Fair and Equitable Treatment Standard under NAFTA Article 1105, 15 Journal of World Investment \& Trade 117 at p. 141 (2014) ("it should be noted that while there is consensus amongst NAFTA tribunals on the customary nature of the prohibition against arbitrary conduct, none of these tribunals have actually gone through the exercise of examining State practice and opinio juris on the matter. In fact, NAFTA tribunals have based their support for this affirmation solely on previous findings of other tribunals.”)

189 See also Windstream Energy LLC v. Canada, UNCITRAL, Award (27 Sept. 2016) (finding breach of MST-FET without identifying supporting state practice or opinio juris despite concordant interpretations from the three NAFTA Parties insisting on those sources as the basis for an asserted customary international law rule); Windstream, US Non-Disputing Party Submission $\S$ 14, 19 ("The twin requirements of State practice and opinio juris must both be identified ... to support a finding that a relevant rule of customary international law has emerged' .... [T] he NAFTA Parties expressly intended Article 1105 (1) to afford the minimum standard of treatment to covered investments, as that standard has crystallized into customary international law through general and consistent State practice and opinio juris. A claimant must demonstrate that alleged standards that are not specified in the treaty has crystallized into an obligation under customary international law.") (citations omitted); Windstream, Mexico Non-Disputing Party Submission, § 7 (expressly agreeing with Canada that "[o]nly States can engage in relevant actions which, if followed out of opinio juris and in concert with enough other States, coalesce into binding custom"; the burden is on the claimant to establish the existence of an obligation under customary international law that meets the requirements of State practice and opinio juris); Windstream, Canada Rejoinder, $\S \S 199$ et seq. (section entitled "The Claimant Bears the Burden of Proving the Existence of a Relevant Rule of Customary International Law Through State Practice and Opinio Juris").

See Glamis Gold Ltd. v. United States, Award (8 June 2009); Cargill Inc. v. Mexico, Award (18 Sept. 2009). 
provisions and ISDS undoubtedly remain tightly interwoven in the debate over the balance between investor protection and the right to regulate.

\section{CONCLUSION}

This paper is a fact-finding contribution to consideration of the balance between investor protection and the right to regulate in investment treaties. It has begun exploring the issues raised by FET, the substantive provision that is often seen to be at the crux of the debate over the right to regulate.

The diversity of interpretations of FET provisions are well known. But the diversity analysed to date has generally been limited to the numerous arbitral interpretations over the last 15 years and the growing range of different treaty provisions. Direct attention to government interpretations of MST-FET reinforces the perception that there is little in common between some different versions of FET. A broad entitlement to fairness for covered foreign investors whose content can be worked out by lawyers, arbitrators and commentators as claimants bring cases using a common-law type method bears little resemblance to a very limited set of rules that can only be expanded through the arduous process of demonstrating widespread state practice and opinio juris.

A key issue in the debate is the issue of interpretive power. The distribution of interpretive power between governments and arbitral tribunals is a recurring issue in the work of the FOI Roundtable. It is a particularly salient issue with regard to FET. 


\section{ANNEX 1: INFORMATION ABOUT CITED TREATIES}

This annex provides the full name (in English where possible) and the date of signature of treaties cited in the paper. In order to facilitate references from the citations in the paper, treaties are listed by alphabetical order of the citation style in the paper. The list includes treaties that have yet to enter into force or are not currently in force, or to be signed.

\begin{tabular}{|c|c|}
\hline As cited in the paper & Full title of agreement \\
\hline AANZFTA & $\begin{array}{l}\text { Agreement Establishing the ASEAN-Australian-New Zealand Free } \\
\text { Trade Area ( } 27 \text { Feb. 2009) }\end{array}$ \\
\hline ACIA Investment Treaty & ASEAN Comprehensive Investment Agreement (26 Feb. 2009) \\
\hline $\begin{array}{l}\text { Additional Protocol to the } \\
\text { Pacific Alliance agreement }\end{array}$ & $\begin{array}{l}\text { Protocolo Adicional al Acuerdo Marco de la Alianza del Pacífico } \\
\text { (10 Feb. 2014) (Chile, Colombia, Mexico and Peru) }\end{array}$ \\
\hline $\begin{array}{l}\text { ASEAN-China Investment } \\
\text { Agreement }\end{array}$ & $\begin{array}{l}\text { Agreement on Investment of the Framework Agreement on } \\
\text { Comprehensive Economic Cooperation Between the People's } \\
\text { Republic of China and the Association of Southeast Asian Nations } \\
\text { (15 Aug. 2009) }\end{array}$ \\
\hline $\begin{array}{l}\text { ASEAN-India Investment } \\
\text { Agreement }\end{array}$ & $\begin{array}{l}\text { Agreement on Investment under the Framework Agreement on } \\
\text { Comprehensive Economic Cooperation Between the Association of } \\
\text { Southeast Asian Nations and the Republic of Indian (12 Nov. 2014) }\end{array}$ \\
\hline $\begin{array}{l}\text { ASEAN-Korea Investment } \\
\text { Agreement }\end{array}$ & $\begin{array}{l}\text { Agreement on Investment under the Framework Agreement on } \\
\text { Comprehensive Economic Cooperation among the Governments of } \\
\text { the Member Countries of the Association of Southeast Asian } \\
\text { Nations and the Republic of Korea ( } 2 \text { June 2009) }\end{array}$ \\
\hline Australia-Korea FTA & $\begin{array}{l}\text { Free Trade Agreement Between the Government of Australia and } \\
\text { the Government of the Republic of Korea (8 April 2014) }\end{array}$ \\
\hline Burkina Faso-Canada BIT & $\begin{array}{l}\text { Agreement Between the Government of Burkina Faso and the } \\
\text { Government of Canada for the Promotion and Protection of } \\
\text { Investments ( } 20 \text { April 2015) }\end{array}$ \\
\hline Canada 2004 Model BIT & $\begin{array}{l}\text { Agreement Between Canada and [Country] for the Promotion and } \\
\text { Protection of Investments (2004) }\end{array}$ \\
\hline Canada-China BIT & $\begin{array}{l}\text { Agreement Between the Government of Canada and the } \\
\text { Government of the People's Republic of China for the Promotion } \\
\text { and Reciprocal Protection of Investments ( } 09 \text { Sept. 2012) }\end{array}$ \\
\hline Canada-Côte d'Ivoire BIT & $\begin{array}{l}\text { Agreement Between the Government of Canada and the } \\
\text { Government of the Republic of Côte D'Ivoire for the Promotion and } \\
\text { Protection of Investments ( } 30 \text { Nov. 2014) }\end{array}$ \\
\hline Canada-Kuwait BIT & $\begin{array}{l}\text { Agreement between Canada and the State of Kuwait for the } \\
\text { Promotion and Protection of Investments ( } 26 \text { Sept. 2011) }\end{array}$ \\
\hline Canada-Mali BIT & $\begin{array}{l}\text { Agreement Between Canada and Mali for the Promotion and } \\
\text { Protection of Investments (28 November 2014) }\end{array}$ \\
\hline
\end{tabular}




\begin{tabular}{|c|c|}
\hline As cited in the paper & Full title of agreement \\
\hline Canada-Nigeria BIT & $\begin{array}{l}\text { Agreement Between Canada and the Federal Republic of Nigeria for } \\
\text { the Promotion and Protection of Investments (6 May 2014) }\end{array}$ \\
\hline Central America-Mexico FTA & $\begin{array}{l}\text { Tratado de Libre Comercio entre los Estados Unidos Mexicanos y } \\
\text { las Repúblicas de Costa Rica, El Salvador, Guatemala, Honduras y } \\
\text { Nicaragua (22 Nov. 2011) }\end{array}$ \\
\hline $\begin{array}{l}\text { Central America-Dominican } \\
\text { Republic FTA (CAFTA-DR) }\end{array}$ & $\begin{array}{l}\text { The Dominican Republic-Central America-United States Free Trade } \\
\text { Agreement (5 Aug. 2004) }\end{array}$ \\
\hline CETA & $\begin{array}{l}\text { The Comprehensive Economic and Trade Agreement between } \\
\text { Canada of the one part, and the European Union and its Member } \\
\text { States, of the other part (signed on } 30 \text { October 2016) }\end{array}$ \\
\hline Chile-Japan FTA & $\begin{array}{l}\text { Agreement Between Japan and the Republic of Chile for a Strategic } \\
\text { Economic Partnership (27 March 2007) }\end{array}$ \\
\hline China-Korea FTA & $\begin{array}{l}\text { Free Trade Agreement Between the Government of the People's } \\
\text { Republic of China and the Government of the Republic of Korea } \\
\text { (1 June 2015) }\end{array}$ \\
\hline Egypt-Mauritius BIT & $\begin{array}{l}\text { Agreement Between the Government of the Arab Republic of the } \\
\text { Egypt and the Government of the Republic of Mauritius on the } \\
\text { Reciprocal Promotion and Protection of Investments (25 June 2014) }\end{array}$ \\
\hline EU-Singapore FTA & $\begin{array}{l}\text { Free Trade Agreement Between the European Union and the } \\
\text { Republic of Singapore (not signed as of } 26 \text { Feb. 2016) }\end{array}$ \\
\hline India-Mexico BIT & $\begin{array}{l}\text { Agreement Between the Government of the Republic of India and } \\
\text { the Government of the United Mexican States on the Promotion and } \\
\text { Protection of Investments ( } 21 \text { May 2007) }\end{array}$ \\
\hline Japan-Philippines EPA & $\begin{array}{l}\text { Agreement Between Japan and the Republic of the Philippines for } \\
\text { an Economic Partnership (9 September 2006) }\end{array}$ \\
\hline Japan-Mexico FTA & $\begin{array}{l}\text { Agreement Between Japan and the United Mexican States for the } \\
\text { Strengthening of the Economic Partnership (17 Sept. 2004) }\end{array}$ \\
\hline Japan-Mongolia EPA & $\begin{array}{l}\text { Agreement Between Japan and Mongolia for an Economic } \\
\text { Partnership (10 Feb. 2015) }\end{array}$ \\
\hline Korea-US FTA & $\begin{array}{l}\text { Trade Agreement Between the United States and the Republic of } \\
\text { Korea (30 June 2007) }\end{array}$ \\
\hline Lisbon Treaty & $\begin{array}{l}\text { Treaty of Lisbon amending the Treaty on European Union and the } \\
\text { Treaty establishing the European Community, signed at Lisbon (13 } \\
\text { December 2007) }\end{array}$ \\
\hline Mexico-Panama FTA & $\begin{array}{l}\text { Tratado de Libre Comercio entre los Estados Unidos Mexicanos y la } \\
\text { República de Panamá (3 April 2014) } \\
\end{array}$ \\
\hline Mexico-Peru FTA & $\begin{array}{l}\text { Acuerdo de Integración Comercial entre la República del Perú y los } \\
\text { Estados Unidos Mexicanos (6 April 2011) }\end{array}$ \\
\hline Mexico-Singapore BIT & $\begin{array}{l}\text { Acuerdo entre el Gobierno de los Estados Unidos Mexicanos y el } \\
\text { Gobierno de la República de Singapur para la Promoción y } \\
\text { Protección Recíproca de las Inversiones (12 Nov. 2009) }\end{array}$ \\
\hline Mexico-UK BIT & $\begin{array}{l}\text { Agreement Between the Government of the United Mexican States } \\
\text { and the Government of the United Kingdom of Great Britain and } \\
\text { Northern Ireland for the Promotion and Reciprocal Protection of } \\
\text { Investments (12 May 2006) }\end{array}$ \\
\hline
\end{tabular}




\begin{tabular}{|l|l|}
\hline As cited in the paper & Full title of agreement \\
\hline NAFTA & North American Free Trade Agreement (1992) \\
\hline Nigeria-Turkey BIT & $\begin{array}{l}\text { Agreement Between the Government of the Republic of Turkey and } \\
\text { the Government of the Federal Republic of Nigeria Concerning } \\
\text { Reciprocal Promotion and Protection of Investments (2 February } \\
\text { 2011) }\end{array}$ \\
\hline Oman-US FTA & $\begin{array}{l}\text { Agreement Between the Government of the Sultanate of Oman and } \\
\text { the Government of the United States of America on the } \\
\text { Establishment of a Free Trade Area (19 January, 2006) }\end{array}$ \\
\hline Peru-US FTA & United States - Peru Trade Promotion Agreement (12 Apr. 2006) \\
\hline Singapore-US FTA & Singapore-United States Free Trade Agreement (6 May 2003) \\
\hline TPP & Trans-Pacific Partnership Agreement (4 Feb. 2016) \\
\hline TTIP & Transatlantic Trade and Investment Partnership (under negotiation) \\
\hline US Model BIT 2012 & $\begin{array}{l}\text { Treaty Between the Government of the United States of America } \\
\text { and the Government of [Country] Concerning the Encouragement } \\
\text { and Protection of Investment (2012) }\end{array}$ \\
\hline
\end{tabular}




\section{ANNEX 2: INFORMATION ABOUT CITED SUBMISSIONS}

\begin{tabular}{|c|c|}
\hline Submission as cited in paper & Full title of document \\
\hline $\begin{array}{l}A D F, \text { Mexico Second Non- } \\
\text { Disputing Party Submission }\end{array}$ & $\begin{array}{l}\text { Second Article } 1128 \text { Submission of The United Mexican States, } 22 \\
\text { July 2002, in ADF Group Inc. vs. United States of America, } \\
\text { ICSID Case No. ARB(AF)/00/1 }\end{array}$ \\
\hline $\begin{array}{l}A D F, \text { US Post-Hearing } \\
\text { Submission }\end{array}$ & $\begin{array}{l}\text { Post-Hearing Submission of Respondent United States of America } \\
\text { on Article } 1105(1) \text { and Pope \& Talbot, } 1 \text { August 2002, in ADF } \\
\text { Group Inc. v. United States of America, ICSID Case No. } \\
\text { ARB(AF)/00/1 }\end{array}$ \\
\hline$A D F$, US Rejoinder & $\begin{array}{l}\text { Rejoinder of Respondent United States of America on Competence } \\
\text { and Liability, } 29 \text { March 2002, in ADF Group Inc. v. United States of } \\
\text { America, ICSID Case No. ARB(AF)/00/1 }\end{array}$ \\
\hline Apotex Holdings, US Rejoinder & $\begin{array}{l}\text { Rejoinder on Merits and Reply on Objections to Jurisdiction of } \\
\text { Respondent United States of America, } 27 \text { September 2013, in } \\
\text { Apotex Holdings Inc. and Apotex Inc. v. The United States of } \\
\text { America, ICSID Case No. ARB(AF)/12/1 }\end{array}$ \\
\hline $\begin{array}{l}\text { Apotex Holdings, US Counter- } \\
\text { Memorial }\end{array}$ & $\begin{array}{l}\text { Counter-Memorial on Merits and Objections to Jurisdiction } \\
\text { of Respondent United States of America, } 14 \text { December 2013, in } \\
\text { Apotex Holdings Inc. and Apotex Inc. v. The United States of } \\
\text { America, Case No. ARB(AF)/12/1 }\end{array}$ \\
\hline $\begin{array}{l}\text { Bilcon, Canada Counter- } \\
\text { Memorial }\end{array}$ & $\begin{array}{l}\text { Counter-Memorial, } 9 \text { December 2011, in William Ralph Clayton, } \\
\text { William Richard Clayton, Douglas Clayton and Daniel Clayton and } \\
\text { Bilcon of Delaware Inc. v. Government of Canada }\end{array}$ \\
\hline $\begin{array}{l}\text { Bilcon, US Non-Disputing } \\
\text { Party Submission }\end{array}$ & $\begin{array}{l}\text { Submission of the United States, } 14 \text { July } 2008 \text {, in William Ralph } \\
\text { Clayton, William Richard Clayton, Douglas Clayton, Daniel } \\
\text { Clayton and Bilcon of Delaware, Inc. v. Canada }\end{array}$ \\
\hline Cargill, Mexico Duplica & $\begin{array}{l}\text { Escrito de Duplica, } 20 \text { August 2007, in Cargill, Inc. c. } \\
\text { Los Estados Unidos Mexicanos, Caso Ciadi No. Arb(AF)/04/05 }\end{array}$ \\
\hline $\begin{array}{l}\text { Chemtura, Canada Counter- } \\
\text { Memorial }\end{array}$ & $\begin{array}{l}\text { Government of Canada, Counter-Memorial, } 20 \text { October 2008, in } \\
\text { Crompton (Chemtura) Corp. v. Government of Canada }\end{array}$ \\
\hline Chemtura, Canada Rejoinder & $\begin{array}{l}\text { Rejoinder Memorial, } 10 \text { July 2009, in Crompton (Chemtura) Corp. } \\
\text { v. Government of Canada }\end{array}$ \\
\hline $\begin{array}{l}\text { Chemtura, US Non-Disputing } \\
\text { Party Submission }\end{array}$ & $\begin{array}{l}\text { Submission of the United States of America, } 31 \text { July 2009, in } \\
\text { Crompton (Chemtura) Corp. v. Government of Canada }\end{array}$ \\
\hline $\begin{array}{l}\text { Eli Lilly, Canada Counter- } \\
\text { Memorial }\end{array}$ & $\begin{array}{l}\text { Canada Counter-Memorial, } 27 \text { Jan. 2015, in Eli Lilly \& Co. v. } \\
\text { Canada }\end{array}$ \\
\hline $\begin{array}{l}\text { Gallo, Canada Statement of } \\
\text { Defence }\end{array}$ & $\begin{array}{l}\text { Government of Canada, Statement of Defence, } 15 \text { September 2008, } \\
\text { in Vito. G. Gallo v. Government of Canada }\end{array}$ \\
\hline Glamis, US Counter-Memorial & $\begin{array}{l}\text { Counter-Memorial, } 19 \text { September 2006, in Glamis Gold, Ltd. v. } \\
\text { United States of America }\end{array}$ \\
\hline
\end{tabular}




\begin{tabular}{|c|c|}
\hline Submission as cited in paper & Full title of document \\
\hline Glamis, US Rejoinder & $\begin{array}{l}\text { Rejoinder, } 15 \text { March 2007, in Glamis Gold, Ltd. v. United States of } \\
\text { America }\end{array}$ \\
\hline $\begin{array}{l}\text { Grand River, US Counter- } \\
\text { Memorial }\end{array}$ & $\begin{array}{l}\text { Counter-Memorial, } 22 \text { December 2008, in Grand River Enterprises } \\
\text { Six Nations, Ltd., Jerry Montour, Kenneth Hill and Arthur Montour, } \\
\text { Jr. v. United States of America }\end{array}$ \\
\hline Grand River, US Rejoinder & $\begin{array}{l}\text { Rejoinder, } 13 \text { May 2009, in Grand River Enterprises Six Nations, } \\
\text { Ltd., Jerry Montour, Kenneth Hill and Arthur Montour, Jr. v. United } \\
\text { States of America }\end{array}$ \\
\hline $\begin{array}{l}\text { Loewen, Mexico Second Non- } \\
\text { Disputing Party Submission }\end{array}$ & $\begin{array}{l}\text { Second article } 1128 \text { Submission of the United Mexican States, } 9 \\
\text { November 2001, The Loewen Group, Inc. and Raymond L. Loewen } \\
\text { v. United States of America, ICSID Case No. Arb(AF)/98/3 }\end{array}$ \\
\hline Loewen, US Counter-Memorial & $\begin{array}{l}\text { Respondent Counter-Memorial, } 30 \text { March 2001, } 30 \text { March 2001, in } \\
\text { The Loewen Group, Inc. and Raymond L. Loewen v. United States of } \\
\text { America, ICSID Case No. Arb(AF)/98/3 }\end{array}$ \\
\hline $\begin{array}{l}\text { Mercer, Canada Counter- } \\
\text { Memorial }\end{array}$ & $\begin{array}{l}\text { Canada Counter-Memorial, } 22 \text { Aug. 2014, in Mercer International } \\
\text { Inc. v. Government of Canada, ICSID Case No. ARB (AF) } 12 /(3)\end{array}$ \\
\hline $\begin{array}{l}\text { Mercer, Canada Rejoinder } \\
\text { Memorial }\end{array}$ & $\begin{array}{l}\text { Canada Rejoinder Memorial, } 31 \text { March 2015, in Mercer } \\
\text { International Inc. v. Government of Canada, ICSID Case } \\
\text { No. ARB(AF) } 12 /(3)\end{array}$ \\
\hline $\begin{array}{l}\text { Merrill, Canada Counter- } \\
\text { Memorial }\end{array}$ & $\begin{array}{l}\text { Canada Counter-Memorial, } 13 \text { May 2008, in Merrill \& Ring } \\
\text { Forestry L.P., v. Canada }\end{array}$ \\
\hline $\begin{array}{l}\text { Mesa, Canada Observations on } \\
\text { Award }\end{array}$ & $\begin{array}{l}\text { Observations on the Award on Jurisdiction and Merits, } 14 \text { May } \\
\text { 2015, in William Ralph Clayton, William Richard Clayton, Douglas } \\
\text { Clayton, Daniel Clayton and Bilcon of Delaware, Inc. v. Canada }\end{array}$ \\
\hline Mesa, Canada Rejoinder & $\begin{array}{l}\text { Rejoinder on the Merits, } 2 \text { July 2014, in Mesa Power Group LLC v. } \\
\text { Government of Canada, PCA Case No. 2012-17 }\end{array}$ \\
\hline $\begin{array}{l}\text { Mesa, Canada Response to } \\
\text { Non-Disputing Party } \\
\text { Submissions }\end{array}$ & $\begin{array}{l}\text { Government of Canada, Response to } 1128 \text { Submissions, } 26 \text { June } \\
\text { 2015, in Mesa Power Group LLC v. Government of Canada, PCA } \\
\text { Case No. 2012-17 }\end{array}$ \\
\hline $\begin{array}{l}\text { Mesa, Mexico Non-Disputing } \\
\text { Party Submission }\end{array}$ & $\begin{array}{l}\text { Submission of Mexico pursuant to NAFTA article } 1128,25 \text { July } \\
\text { 2014, in Mesa Power Group LLC v. Government of Canada, PCA } \\
\text { Case No. 2012-17 }\end{array}$ \\
\hline $\begin{array}{l}\text { Mesa, Mexico Second Non- } \\
\text { Disputing Party Submission }\end{array}$ & $\begin{array}{l}\text { Second Submission of Mexico Pursuant to NAFTA article 1128, in } \\
\text { Mesa Power Group LLC v. Government of Canada, PCA Case No. } \\
\text { 2012-17 }\end{array}$ \\
\hline $\begin{array}{l}\text { Mesa, US Non-Disputing Party } \\
\text { Submission }\end{array}$ & $\begin{array}{l}\text { Submission of The United States of America, } 31 \text { July 2009, in Mesa } \\
\text { Power Group LLC v. Government of Canada, PCA Case No. 2012- } \\
17\end{array}$ \\
\hline $\begin{array}{l}\text { Mesa, US Second Non- } \\
\text { Disputing Party Submission }\end{array}$ & $\begin{array}{l}\text { Second Submission of The United States of America, } 12 \text { June } 2015 \text {, } \\
\text { in Mesa Power Group LLC v. Government of Canada, PCA Case } \\
\text { No. 2012-17 }\end{array}$ \\
\hline
\end{tabular}




\begin{tabular}{|l|l|}
\hline Submission as cited in paper & Full title of document \\
\hline $\begin{array}{l}\text { Methanex, Mexico Fourth Non- } \\
\text { Disputing Party Submission }\end{array}$ & $\begin{array}{l}\text { Fourth article 1128 Submission of the United Mexican States, } 30 \\
\text { January 2004, in Methanex Corporation v. The United States } \\
\text { of America }\end{array}$ \\
\hline $\begin{array}{l}\text { Methanex, Mexico Third Non- } \\
\text { Disputing Party Submission }\end{array}$ & $\begin{array}{l}\text { Third article 1128 Submission of the United Mexican States, } 11 \\
\text { February 2002, in Methanex Corporation v. The United States } \\
\text { of America }\end{array}$ \\
\hline $\begin{array}{l}\text { Mobil, Canada, Counter- } \\
\text { Memorial }\end{array}$ & $\begin{array}{l}\text { Government of Canada, Counter-Memorial, 1 December 2009, in } \\
\text { Mobil Investments Canada Inc. and Murphy Oil Corporation } v\end{array}$ \\
\hline Canada, ICSID Case No. ARB(AF)/07/4
\end{tabular}




\title{
OECD Working Papers on International Investment
}

\author{
www.oecd.org/investment/working-papers.htm
}

2017/2 The balance between investor protection and the right to regulate in investment treaties: A scoping paper

2017/1 Foreign direct investment, corruption and the OECD Anti-Bribery Convention

State-to-State dispute settlement and the interpretation of investment treaties

Investment policies related to national security

The legal framework applicable to joint interpretive agreements of investment treaties

Currency-based measures targeting banks - Balancing national regulation of risk and financial openness

Temporal validity of international investment agreements: a large sample survey of treaty provisions

China Investment Policy: an Update

\section{2}

\section{0}

Investor-state dispute settlement: A scoping paper for the investment policy community Dispute settlement provisions in international investment agreements: A large sample survey Corporate greenhouse gas emission reporting: A stocktaking of government schemes

Defining and measuring green FDI: An exploratory review of existing work and evidence Environmental concerns in international investment agreements: a survey

OECD's FDI Restrictiveness Index: 2010 Update

Foreign state immunity and foreign government controlled investors

Intellectual property rights in international investment agreements

OECD's FDI regulatory restrictiveness index: Revision and extension to more economies Interpretation of the Umbrella Clause in Investment Agreements Investor-State Dispute Settlement in Infrastructure Projects Improving the System of Investor-State Dispute Settlement: An Overview 
2005/3 Corporate Responsibility Practices of Emerging Market Companies - A Fact-Finding Study

2005/2 Multilateral Influences on the OECD Guidelines for Multinational Enterprises

2005/1 Transparency and Third Party Participation in Investor-State Dispute Settlement Procedures

\section{4}

$2004 / 6$

\section{0}

\section{9}

1999/3 Rules for the Global Economy: Synergies between Voluntary and Binding Approaches

$1999 / 2$

$1999 / 1$

Mobilising Investment for Development: Role of ODA - The 1993-2003 Experience in Vietnam

ODA and Investment for Development: What Guidance can be drawn from Investment Climate Scoreboards?

Indirect Expropriation and the Right to Regulate in International Investment Law

Fair and Equitable Treatment Standard in International Investment Law

Most-Favoured-Nation Treatment in International Investment Law

Relationships between International Investment Agreements

\section{Business Approaches to Combating Corrupt Practices}

Incentives-based Competition for Foreign Direct Investment: The Case of Brazil

Managing Working Conditions in the Supply Chain: A Fact-Finding Study of Corporate Practices

Multinational Enterprises in Situations of Violent Conflict and Widespread Human Rights Abuses

\section{Codes of Corporate Conduct: Expanded review of their contents}

The OECD Guidelines for Multinational Enterprises and other corporate responsibility instruments Public policy and voluntary initiatives: What roles have governments played?

Making codes of corporate conduct work: Management control systems and corporate responsibility

Corporate Responsibility: Results of a fact-finding mission on private initiatives

Private Initiatives for Corporate Responsibility: An Analysis

Recent trends, policies and challenges in South East European countries

Main determinants and impacts of FDI on China's economy

Lithuania: Foreign Direct Investment Impact and Policy Analysis

Investment Patterns in a Longer-Term Perspective

Bribery and the business sector: Managing the relationship

\section{8}

1998/1 Survey of OECD work on international investment 